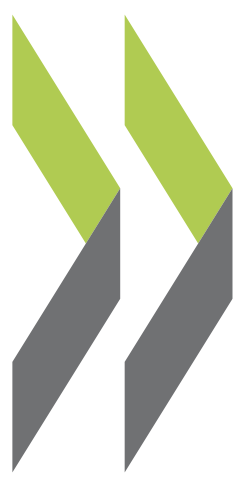

OECD Economics Department Working Papers No. 988 Current Account Benchmarks for Turkey 
Organisation de Coopération et de Développement Économiques

Organisation for Economic Co-operation and Development

14-Sep-2012

ECONOMICS DEPARTMENT

English - Or. English

\section{CURRENT ACCOUNT BENCHMARKS FOR TURKEY}

ECONOMICS DEPARTMENT WORKING PAPERS No. 988

\section{By Oliver Röhn}

All Economics Department Working Papers are available through OECD's Internet website at http://www.oecd.org/eco/workingpapers

JT03326290

Complete document available on OLIS in its original format

This document and any map included herein are without prejudice to the status of or sovereignty over any territory, to the delimitation of international frontiers and boundaries and to the name of any territory, city or area. 


\section{ABSTRACT/RÉSUMÉ}

\section{Current account benchmarks for Turkey}

Turkey's current account deficit widened to almost 10\% of GDP in 2011 and has been narrowing only gradually since. An important question is to what extent Turkey's current account deficit is excessive. To explore this issue, one needs to establish benchmarks. In this paper current account benchmarks are derived using the external sustainability as well as the macroeconomic balance approach. However, the standard macroeconomic balance approach ignores the uncertainty inherent in the model selection process given the relatively large number of possible determinants of current account balances. This paper therefore extends the macroeconomic balance approach to account for model uncertainty by using Bayesian Model Averaging techniques. Results from both approaches suggest that current account benchmarks for the current account deficit lie in the range of $3 \%$ to $5 \frac{1}{2}$ per cent of GDP, which is broadly in line with previous estimates but substantially below recent current account deficit levels.

This Working Paper relates to the 2012 OECD Economic Survey of Turkey (www.oecd.org/eco/surveys/turkey).

JEL classification: C11; F32; F41.

Keywords: Turkey; current account; external sustainability; current account benchmarks; model uncertainty; Bayesian Model Averaging.

\section{Des repères pour la balance courante en Turquie}

Le déficit de la balance des opérations courantes de la Turquie s'est creusé pour atteindre près de $10 \%$ du PIB en 2011 et n'a rétréci que très graduellement depuis. Il importe de déterminer dans quelle mesure ce déficit est excessif. Pour explorer la question, des repères doivent être établis. Ce document de travail calcule et propose de tels repères, à partir des méthodes de viabilité de la balance courante, et d'équilibre macroéconomique. La méthode standard d'équilibre macroéconomique ne tient cependant pas compte de l'incertitude inhérente au processus de sélection du modèle, vu le nombre important de déterminants possibles de la balance des opérations courantes. Ce document élargit la méthode d'équilibre macroéconomique afin de tenir compte de cette incertitude, en utilisant les techniques de choix de modèles par estimateur Bayesien. Les résultats obtenus à partir des deux méthodes suggèrent que les repères de balance courante pour la Turquie pourraient se situer entre $3 \%$ et $5 \frac{1}{2}$ pour cent du PIB, en ligne avec les estimations précédentes mais nettement en-dessous des récents niveaux de déficit du compte courant.

Ce Document de travail se rapporte à l'Étude économique de l'OCDE de la Turquie, 2012 (www.oecd.org/eco/surveys/turkey).

Classification JEL: C11; F32; F41.

Mots clés : Turquie ; balance courante ; viabilité des comptes extérieurs ; repères pour la balance courante ; incertitude relative au modèle ; choix de modèles par estimateur Bayesien.

\section{OECD (2012)}

You can copy, download or print OECD content for your own use, and you can include excerpts from OECD publications, databases and multimedia products in your own documents, presentations, blogs, websites and teaching materials, provided that suitable acknowledgment of OECD as source and copyright owner is given. All requests for commercial use and translation rights should be submitted to rights@oecd.org 


\section{TABLE OF CONTENTS}

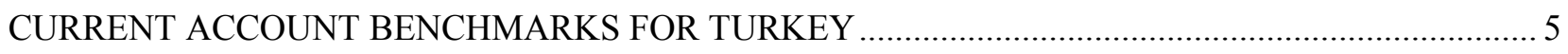

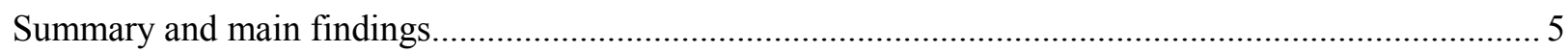

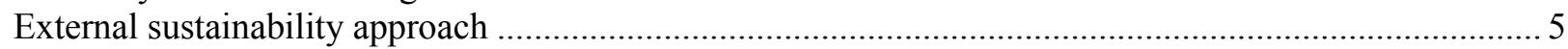

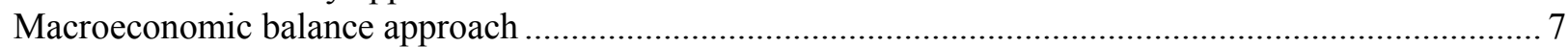

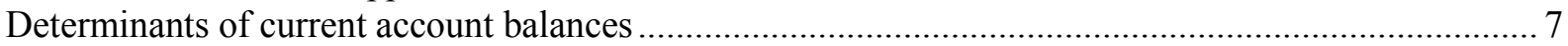

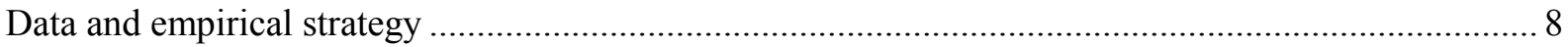

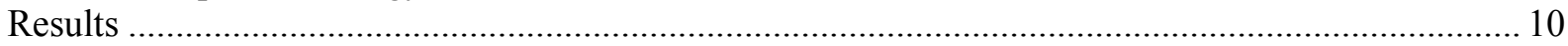

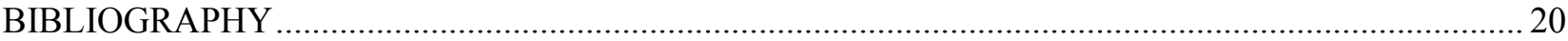

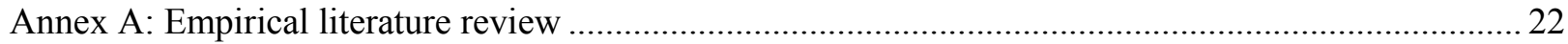

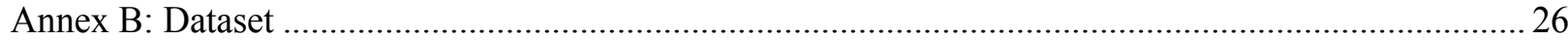

\section{Tables}

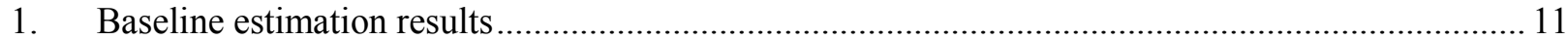

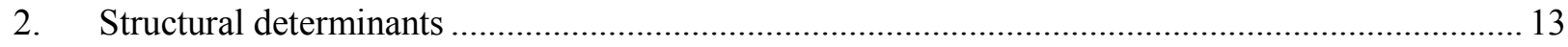

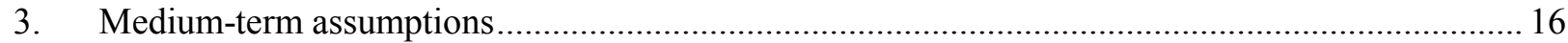

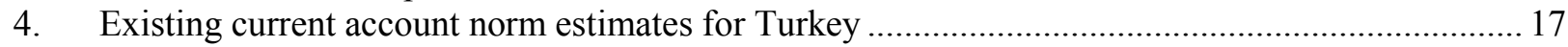

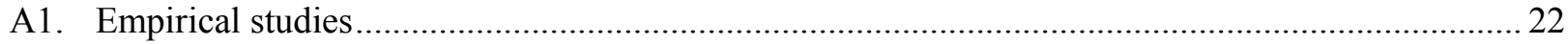

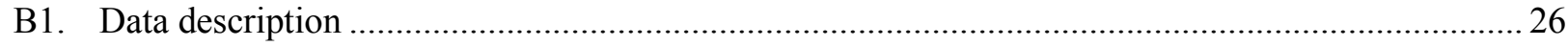

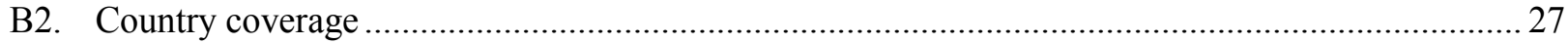

\section{Figures}

1. Baseline: Actual and fitted current account balance …............................................................. 12

2. Structural policies: Actual and fitted current account balance................................................... 15

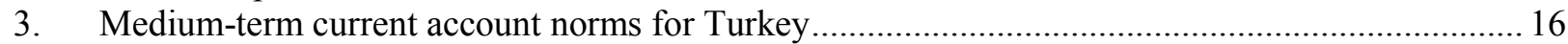

4. Current account norm deviations and external competitiveness …............................................. 18

5. Current account norm deviations and cyclical factors ............................................................... 19 
ECO/WKP(2012)65 
ECO/WKP(2012)65

\title{
CURRENT ACCOUNT BENCHMARKS FOR TURKEY
}

\author{
By Oliver Röhn ${ }^{1}$
}

\section{Summary and main findings}

1. Turkey's current account deficit widened to almost 10\% of GDP in 2011 and has been narrowing only gradually since. A sizeable current account deficit is not uncommon for catching-up economies which, given a certain level of political and macroeconomic stability as well as security of property rights, provide ample investment opportunities and high returns for foreign investors. For instance, new EU member countries in Central and Eastern Europe have experienced deficits of similar magnitude. An important question is therefore if and to what extent Turkey's current account deficit is excessive. To explore this issue, one needs to establish current account benchmarks.

2. In this paper current account benchmarks are derived using the external sustainability as well as the macroeconomic balance approach. Both approaches are part of the IMF's Consultative Group on Exchange Rate Issues (CGER) assessment of equilibrium exchange rates (Lee et al., 2008). However, the standard macroeconomic balance approach ignores the uncertainty inherent in the model selection process given the relatively large number of possible determinants of current account balances. This paper therefore extends the macroeconomic balance approach to account for model uncertainty by using Bayesian Model Averaging (BMA) techniques. BMA allows examining a large number of models, weighing each one according to a data fitness criterion. Results from both approaches suggest that current account benchmarks for the current account deficit lie in the range of $3 \%$ to $5 \frac{1}{2} \%$ of GDP, which is broadly in line with previous estimates but substantially below the recent current account deficit of about 9\% of GDP (2012Q1).

\section{External sustainability approach}

3. The external sustainability approach rests on simple accounting, using the balance of payments identities (Lane and Milesi-Ferretti, 2006). The derived current account benchmark ensures that the net foreign asset position remains stable at some (arbitrary) level. A standard choice for this level is the currently observed net foreign asset position. Besides this choice, the approach only requires assumptions about real GDP growth and inflation.

4. The approach starts from the simple balance of payments accounting identity:

$$
C A_{t}+K_{t}+F A_{t}+E O_{t}=0
$$

1. OECD Economics Department. This paper provides background analysis conducted for the $O E C D$ Economic Survey of Turkey published in July 2012. The author would like to thank Vincent Koen, Rauf Gönenç, Cyrille Schwellnus, Andrew Dean and Robert Ford for valuable comments and Chloé MartinLaval for excellent research assistance. Special thanks go to Nadine Dufour and Pascal Halim for technical preparation. 
where $C A_{t}, K_{t}, F A_{t}, E O_{t}$ are the current account, capital account, financial account and errors and omissions, respectively. In addition, the net foreign asset position at any point in time, $N F A_{t}$, is given by:

$$
N F A_{t}=N F A_{t-1}-F A_{t}+K G_{t},
$$

where $K G_{t}$ represents capital gains. Combining equations (1) and (2), assuming for simplicity that the capital account $K_{t}$ and capital gains $K G_{t}$ are zero, and denoting ratios to GDP in lower case letters yields:

$$
n f a_{t}-n f a_{t-1}=c a_{t}+e o_{t}-\frac{g_{t}+\pi_{t}+g_{t} * \pi_{t}}{1+g_{t}+\pi_{t}+g_{t} * \pi_{t}} n f a_{t-1}
$$

where $g_{t}$ and $\pi_{t}$ are the real GDP growth and the rate of change in the GDP deflator, respectively. The current account level that stabilises the net foreign asset position at a given level can then be expressed as:

$$
c a_{t}^{S}=\frac{g_{t}+\pi_{t}+g_{t} * \pi_{t}}{1+g_{t}+\pi_{t}+g_{t} * \pi_{t}} n f a^{S}-e o_{t}
$$

5. Calculations of this sort show that, assuming 5\% real GDP growth and GDP inflation, similar to the assumptions in Turkey's 2012-14 Medium Term Programme, and net errors and omissions amounting to $1 \%$ of GDP in line with historical averages, a stable net foreign asset position at the current level (2012Q1) of $-48 \%$ of GDP is consistent with a current account deficit of 5.4\% of GDP. Even if real GDP growth of $7 \%$ is assumed, the stabilising current account deficit increases only to $6.3 \%$ of GDP. Both are well below the current deficit of about 9\% of GDP observed in 2012Q1.

6. Alternatively, it might be more relevant to consider stabilising the gross external debt position, as FDI and other equity liabilities are generally not considered to compromise sustainability. In this case it is necessary to adjust the current account for non-debt creating flows. To this end, the financial account $F A_{t}$ can be decomposed into different types of flows, namely equity (FDI and portfolio equity) versus debt (portfolio debt and other investment) flows.

$$
F A_{t}=\left(H_{t, \text { equity, }}-H_{t, \text { equity }, A}\right)+\left(H_{t, \text { debt }, \mathrm{L}}-H_{t, \text { debt }, A}\right) \text {, }
$$

where $H_{t, j, A}, H_{t, j, L}$ are asset and liability flows, respectively. Assuming again no valuation gains or losses, gross foreign debt at any point in time, $G F D_{t}$, is given by:

$$
G F D_{t}=G F D_{t-1}+H_{t, d e b t, L}
$$

Assuming further a balanced capital account, the change in gross foreign debt in per cent of GDP can be expressed as:

$$
g f d_{t}-g f d_{t-1}=-\left(c a_{t}+h_{t, \text { equity }, L}-h_{t, \text { equity }, A}-h_{t, \text { debt }, A}\right)-e o_{t}-\frac{g_{t}+\pi_{t}+g_{t} * \pi_{t}}{1+g_{t}+\pi_{t}+g_{t} * \pi_{t}} g f d_{t-1}
$$

It follows that the adjusted current account balance to stabilise gross foreign debt is given by:

$$
\left(c a_{t}+h_{t, \text { equity }, L}-h_{t, \text { equity }, A}-h_{t, \text { debt }, A}\right)^{S}=-e o_{t}-\frac{g_{t}+\pi_{t}+g_{t} * \pi_{t}}{1+g_{t}+\pi_{t}+g_{t} * \pi_{t}} g f d^{s}
$$

7. Under the baseline of 5\% real GDP growth and inflation, stability of the gross external debt ratio at its latest observed level of 40\% (2012Q1) of GDP obtains with an adjusted current account deficit of $4.7 \%$ of GDP. Under the alternative assumption of $7 \%$ real GDP growth, the adjusted current account deficit could increase to $5.4 \%$. Neither is far from the actual adjusted deficit of $6.3 \%$ in 2012(Q1). 


\section{Macroeconomic balance approach}

8. The macroeconomic balance approach proceeds in two steps. In the first step, an equilibrium relationship between the current account and a set of fundamental investment and saving determinants is estimated in a panel regression setup. In the second step, a current account norm is derived based on the estimated relationship and projected values of the fundamental determinants in the medium term (five years), by which countries are assumed to have restored internal equilibrium and operate at potential output.

9. The notion of a current account norm is, however, somewhat misleading as some determinants entering the estimations are "undesirable" fundamentals such as the oil import bill and the fiscal deficit (see below). Thus, all else equal, a more energy inefficient economy or spendthrift government would imply a lower norm for the current account balance. Norm estimates therefore rather summarise average current account tendencies given reasonable assumptions about medium-term developments of the fundamentals.

\section{Determinants of current account balances}

10. A range of determinants have been suggested in the literature explaining equilibrium movements of the current account mainly through their impact on saving and investment. In the following, some theoretical considerations underlying these factors are briefly reviewed. ${ }^{2}$ Annex A provides an overview of recent empirical findings and Table B1 in Annex B the specific variables included in the subsequent empirical analysis.

- Initial net foreign asset position. A higher initial net asset position is associated with positive investment income flows which improve the current account. On the other hand a highly indebted country may have to eventually improve its current account position to preserve solvency. Hence the theoretically expected sign is ambiguous. However, the vast majority of empirical studies find a positive link.

- Demographic factors influence mainly the saving behaviour of an economy. The life-cycle hypothesis for instance suggests that savings are accumulated during the working age while younger and older age cohorts generally dissave. Thus a country with a high old and/or young age dependency ratio should generally be expected to save relatively less.

- Oil dependency. Higher oil prices improve the current account balance of oil exporters while they reduce the balance of oil importers. The oil trade balance is generally included in regressions to allow the effect of oil prices to differ across countries and the sign is expected to be positive.

- Fiscal policy. In the absence of full Ricardian equivalence, i.e. when changes in private and public saving do not fully offset each other, higher budget deficits reduce overall domestic saving and thus the current account balance.

- Stage of economic development. Countries with low income are expected to run current account deficits due to their low saving and high investment growth during the convergence process to higher income per capita levels. Thus the relationship between relative income and the current account should be positive. To allow for non-linearities in this relationship, a squared term is frequently included in the regressions with a theoretically ambiguous sign. In addition, GDP

2. A more comprehensive discussion of the theories can be found for example in Cheung et al. (2010) and Kerdrain et al. (2010). 
growth is included. The effect of GDP growth on saving is ambiguous and depends inter alia on whether the associated increase in income is perceived as temporary or permanent and the degree of consumption smoothing of economic agents. Higher growth rates resulting from productivity gains may raise expected asset returns leading to higher investment. Most empirical studies find a negative link between GDP growth and the current account.

- Uncertainty may increase the current account balance due to higher precautionary savings and/or reduced investment. Here the inflation rate is used as an imperfect proxy for uncertainty (as in Loayza et al., 2000) and the expected sign is positive.

- Trade integration is commonly used in the literature as a proxy for barriers to trade and may be correlated with other attributes that make a country attractive to foreign capital. However, the majority of empirical studies find a positive link.

- Changes in terms of trade may affect saving if the shock is perceived to be transitory. In this case consumption-smoothing households would adjust their saving in response to the transitory change in real income.

- Financial development and integration. According to the "saving glut" hypothesis (Bernanke, 2005), developing countries (in particular in Asia) have bypassed their inefficient domestic financial markets and exported savings to countries with more sophisticated financial markets. Hence, greater financial market development in developing countries may reduce their saving and current account balance. This effect may be reinforced if expanding financial intermediation reduces borrowing constraints and the need for precautionary savings. On the other hand, financial market development may reduce transaction costs and facilitate risk management, thereby encouraging saving. The overall effect of financial development on the current account is therefore ambiguous and may depend on the country under consideration as well as on the specific indicator employed. In this paper a wide range of proxies for financial development is used.

- Institutional and regulatory quality. Improving the quality of the legal and regulatory system should in general attract investment and thus lead to a reduction in the current account balance. However, labour market reforms may raise the overall employment rate with positive effects on household income and saving.

11. In addition, a range of dummy variables have been suggested in the literature. For instance Asian countries may have permanently increased their saving rate to insure themselves against future external shocks since the financial crisis in 1997/98. Furthermore, economies that serve as hubs for international financial flows have tended to run substantial current account surpluses and net creditor positions. Furthermore, euro area membership may have boosted credit growth and investment in the less developed euro area periphery countries beyond what can be explained by fundamentals (Barnes et al., 2010). Similarly, the completion of EU accession negotiations in eastern European countries may have led to "EU-phoria" (Rahman, 2008) induced temporary surges in capital inflows and credit growth or more permanently raised expectations of future improvements of the legal and regulatory system.

\section{Data and empirical strategy}

12. An unbalanced dataset is used including at most 52 countries ( 29 emerging, 23 industrial) over the time period 1985-2010. In line with previous approaches (see Annex A), i) most variables are expressed as deviations from a GDP-weighted world mean since the current account balance of one country is not only affected by domestic determinants but also by developments in the rest of the world; and ii) five-year non-overlapping averages of the annual observations are used to filter out cyclical movements and focus on medium-term developments (for more details see Annex B, Tables B1 and B2). 
13. Following standard practice in the literature (e.g. Chinn and Prasad, 2003), pooled ordinary least squares (OLS) is used to estimate the following reduced-form current account model:

$$
C A_{i, t}=\alpha+\beta X_{i, t}+\gamma Z_{i, t}+\epsilon_{i, t}
$$

where $C A_{i, t}$ is the current account balance in per cent of GDP, $X_{i, t}$ is a vector of standard macroeconomic variables and $Z_{i, t}$ a vector of financial and institutional variables. Standard caveats regarding endogeneity of the right-hand side variables apply in this simple framework, although net foreign assets are measured at the beginning of each five-year period to mitigate this problem. Results should therefore be interpreted with caution and be viewed as a summary of past historical relationships rather than to draw strong causal conclusions.

14. More recently this standard approach of estimating current account balances has been criticised for ignoring the issue of model uncertainty given the large number of potential current account determinants (Ca'Zorzi et al., 2009, 2012; Bussière et al., 2010). Ca'Zorzi et al. (2009) analyse this issue in detail and show that even adopting a transparent approach, different economic and statistical criteria would yield different models. They conclude that there appears to be no "true" model which can easily be labelled as superior to all others. Ignoring such model uncertainty can result in biased parameter estimates, overconfident (too narrow) standard errors and misleading inference and predictions (Draper, 1995).

15. Against this background, Bayesian Model Averaging (BMA) techniques are applied below so as to account for the uncertainty inherent in the model selection process. BMA has been applied extensively in the economic growth literature to deal with model uncertainty (e.g. Fernandez et al., 2001; Sala-i-Martin et al., 2004) and was recently advocated by Bussière et al. (2010) in the context of reduced-form current account estimations. Below, a larger set of financial and institutional variables is tried out. Given the 35 explanatory variables considered here, there are more than 34 billion potential models to explain current account balances. BMA allows examining a large number of models, weighing each one according to a fitness criterion, and providing a probability distribution for each coefficient estimate. More details on BMA in general and the specific approach used here, including the always contentious choice in Bayesian analysis of the prior distribution specifications, can be found in Wölfl et al. (2010). In the following, only the most important summary statistics are described.

16. The posterior inclusion probability of a variable provides a probability measure of how important a variable is in explaining the dependent variable and is given by:

$$
\operatorname{Pr}(\beta \neq 0 \mid D)=\sum_{A} P\left(M_{j} \mid D\right), \quad \text { with } A \in\left\{M_{k}: j=1, \ldots J ; \beta \neq 0\right\}
$$

The posterior inclusion probability is thus the sum of the posterior model probabilities given the data of the models that contain the particular variable of interest. The posterior model probability can be viewed as a measure of relative data fit. Under specific assumptions about prior parameter distribution, the posterior model probability can be approximated with the Bayesian Information Criterion (BIC) (Raftery, 1995; Hoeting et al., 1999). If the posterior inclusion probability is higher than the prior inclusion probability ( $50 \%$ by default), one can conclude that the variable of interest is effective in explaining the dependent variable (see below).

17. The posterior mean and the posterior standard deviation of a particular coefficient are additional important statistics and are given by:

$$
\mathrm{E}(\beta \mid \mathrm{D})=\sum_{\mathrm{j}=1}^{2^{\mathrm{k}}} \mathrm{E}\left(\beta_{\mathrm{j}} \mid \mathrm{D}, \mathrm{M}_{\mathrm{j}}\right) \mathrm{P}\left(\mathrm{M}_{\mathrm{j}} \mid \mathrm{D}\right)
$$




$$
\operatorname{Var}(\beta \mid D)=\sum_{j=1}^{2^{\mathrm{k}}}\left(\operatorname{Var}\left(\beta_{\mathrm{j}} \mid \mathrm{D}, \mathrm{M}_{\mathrm{j}}\right)+\mathrm{E}\left(\beta_{\mathrm{j}} \mid \mathrm{D}, \mathrm{M}_{\mathrm{j}}\right)^{2}\right) \mathrm{P}\left(\mathrm{M}_{\mathrm{j}} \mid \mathrm{D}\right)-\mathrm{E}(\beta \mid \mathrm{D})^{2}
$$

The model-specific means $E\left(\beta_{\mathrm{j}} \mid \mathrm{D}, \mathrm{M}_{\mathrm{j}}\right)$ and variances $\operatorname{Var}\left(\beta_{\mathrm{i}} \mid \mathrm{D}, \mathrm{M}_{\mathrm{j}}\right)$ can be conveniently approximated with the maximum likelihood (ML) point and variance estimates (Raftery, 1995), which are equivalent to the OLS estimates in linear regression models. Using this ML or OLS approximation together with the BIC approximation for the posterior model probability, the BMA approach used here is conceptually similar to the Bayesian Averaging of Classical Estimates (BACE) approach of Sala-i-Martin et al. (2004).

\section{Results}

Baseline

18. In the baseline estimations only the most-frequently-employed macroeconomic determinants of current account balances are included. Table 1 displays the posterior inclusion probability, the conditional (on the variable being included in a model) means, standard deviations and t-statistics, for the full sample and the sub-samples of emerging and industrialised countries. To judge the robustness of a regressor in explaining the current account balance, the interpretation of the results follows a rule of thumb proposed by Jeffreys (1961) and refined by Kass and Raftery (1995). According to this rule, the evidence of a regressor having an effect is weak, positive, strong, or decisive if the posterior inclusion probabilities lie between 50$75 \%, 75 \%-95 \%, 95 \%-99 \%$ or are greater than $99 \%$, respectively.

19. The results in Table 1 indicate that only a handful of determinants proposed in the literature are robustly related to the current account. In particular, the full sample results show that only the initial net foreign asset position, the oil balance, the Asian crisis dummy, the euro periphery dummy and the EU accession dummy are robustly related to the current account balance. Taking the estimated coefficients at face value, an improvement of the initial net foreign asset position of 10 percentage points of GDP is estimated to increase the current account balance subsequently by 0.5 percentage points of GDP, while an improvement of the oil balance of the same magnitude would lead to an increase of the current account balance by 3.5 percentage points of GDP. The estimates further imply that completion of EU accession negotiations was associated with a subsequent decline of the external balance on average by 5.4 percentage points of GDP in eastern European countries, whereas Asian countries improved their balance on average by 5 percentage points of GDP following the crisis in 1997/98. Finally, the dummy for euro area periphery countries suggests that euro area membership boosts the current account deficit of periphery countries by about 3 percentage points of GDP beyond what can be explained by fundamentals.

20. The results for the sub-sample of emerging countries are very similar to the full sample results. However, in the sub-sample of industrialised countries several additional variables become robustly related to the current account. In particular, the estimates suggest that a 1 percentage point improvement of the budget balance in terms of GDP (relative to the rest of the world) improves the current account balance by 0.3 percentage points of GDP, which implies that Ricardian equivalence does not hold. Furthermore, a 10 percentage point increase in trade openness (relative to the rest of the world) improves the current account by 0.3 percentage points, while a 1 percentage point faster population growth relative to other countries would worsen the current account by 3 percentage points. 
Table 1. Baseline estimation results

$\mathrm{ECO} / \mathrm{WKP}(2012) 65$

\begin{tabular}{|c|c|c|c|c|c|c|c|c|c|c|c|c|}
\hline \multirow[b]{2}{*}{ Variable } & \multicolumn{4}{|c|}{ Full sample } & \multicolumn{4}{|c|}{ Emerging market economies } & \multicolumn{4}{|c|}{ Industrialised countries } \\
\hline & $\begin{array}{l}\text { Posterior } \\
\text { inclusion } \\
\text { probability }\end{array}$ & $\begin{array}{c}\text { Conditional } \\
\text { mean }\end{array}$ & $\begin{array}{l}\text { Conditional } \\
\text { standard } \\
\text { deviation }\end{array}$ & $\begin{array}{l}\text { Conditional } \\
\text { t-statistic }\end{array}$ & $\begin{array}{l}\text { Posterior } \\
\text { inclusion } \\
\text { probability }\end{array}$ & $\begin{array}{c}\text { Conditional } \\
\text { mean }\end{array}$ & $\begin{array}{l}\text { Conditional } \\
\text { standard } \\
\text { deviation }\end{array}$ & $\begin{array}{l}\text { Conditional } \\
\text { t-statistic }\end{array}$ & $\begin{array}{l}\text { Posterior } \\
\text { inclusion } \\
\text { probability }\end{array}$ & $\begin{array}{c}\text { Conditional } \\
\text { mean }\end{array}$ & $\begin{array}{l}\text { Conditional } \\
\text { standard } \\
\text { deviation }\end{array}$ & $\begin{array}{c}\text { Conditional } \\
\text { t-statistic }\end{array}$ \\
\hline Initial net foreign assets & 100 & 0.048 & 0.007 & 6.713 & 100 & 0.041 & 0.011 & 3.665 & 100 & 0.062 & 0.009 & 6.998 \\
\hline Oil trade balance & 100 & 0.366 & 0.052 & 7.025 & 100 & 0.318 & 0.051 & 6.174 & 70 & 0.364 & 0.144 & 2.523 \\
\hline Inflation & 2 & 0.004 & 0.007 & 0.531 & 25 & 0.018 & 0.010 & 1.782 & 7 & 0.007 & 0.024 & 0.288 \\
\hline Trade openness & 6 & -0.008 & 0.006 & -1.297 & 11 & -0.009 & 0.006 & -1.514 & 98 & 0.034 & 0.010 & 3.389 \\
\hline Budget balance & 30 & 0.136 & 0.068 & 1.999 & 2 & -0.031 & 0.104 & -0.302 & 96 & 0.317 & 0.108 & 2.945 \\
\hline Relative income & 7 & 0.008 & 0.007 & 1.219 & 3 & 0.001 & 0.024 & 0.037 & 18 & 0.034 & 0.018 & 1.864 \\
\hline Relative income squared & 16 & 0.000 & 0.000 & 1.690 & 5 & 0.000 & 0.000 & -0.806 & 19 & 0.000 & 0.000 & 1.969 \\
\hline GDP growth & 2 & 0.047 & 0.115 & 0.405 & 5 & 0.132 & 0.119 & 1.102 & 2 & 0.034 & 0.235 & 0.145 \\
\hline Old age & 7 & 0.057 & 0.039 & 1.445 & 7 & -0.073 & 0.064 & -1.149 & 2 & -0.046 & 0.126 & -0.369 \\
\hline Young age & 3 & 0.022 & 0.050 & 0.430 & 3 & -0.007 & 0.036 & -0.209 & 8 & 0.111 & 0.092 & 1.211 \\
\hline Population growth & 7 & -0.485 & 0.394 & -1.231 & 5 & 0.370 & 0.389 & 0.952 & 100 & -2.930 & 0.732 & -4.003 \\
\hline Terms of trade growth & 1 & 0.024 & 0.090 & 0.266 & 6 & 0.105 & 0.101 & 1.036 & 2 & 0.000 & 0.156 & 0.001 \\
\hline Asia dummy & 100 & 4.915 & 0.899 & 5.469 & 100 & 5.782 & 0.879 & 6.581 & & & & \\
\hline Financial centre & 49 & 2.467 & 1.125 & 2.193 & 27 & -4.514 & 2.458 & -1.836 & 6 & 1.688 & 1.369 & 1.233 \\
\hline Euro core dummy & 13 & 1.773 & 1.086 & 1.633 & & & & & 3 & 0.471 & 1.156 & 0.407 \\
\hline Euro periphery dummy & 75 & -2.919 & 1.070 & -2.728 & & & & & 65 & -2.469 & 1.059 & -2.331 \\
\hline EU accession dummy & 100 & -5.422 & 1.330 & -4.077 & 100 & -5.385 & 1.244 & -4.331 & & & & \\
\hline Financial integration & 22 & -0.002 & 0.001 & -1.898 & 13 & -0.003 & 0.002 & -1.520 & 7 & -0.002 & 0.002 & -1.122 \\
\hline Labour force participation & 1 & 0.001 & 0.035 & 0.034 & 7 & 0.052 & 0.044 & 1.186 & 5 & -0.039 & 0.059 & -0.664 \\
\hline No of countries & & & 52 & & & & 29 & & & & 23 & \\
\hline No of observations & & & 232 & & & & 119 & & & & 113 & \\
\hline
\end{tabular}

Note: All regressions include an intercept and time dummies but are not reported. To judge the effectiveness of a regressor in explaining the current account, a rule of thumb proposed by Jeffreys (1961) and refined by Kass and Raftery (1995) is used. According to this rule, the evidence of a regressor having an effect is weak, positive, strong, or decisive if the posterior inclusion probabilities lie between $50-75 \%, 75 \%-95 \%, 95 \%-99 \%$ or are greater than $99 \%$, respectively.

Source: OECD estimates 
21. Figure 1 plots the fitted values based on the full and the emerging market samples (using fiveyear moving averages of the explanatory variables) together with the actual current account balance for Turkey. For the 1990s the estimated and actual current account deficits are relatively similar. While the actual current account deficit hovered around 1\% of GDP, estimates from both samples imply a deficit of about $2 \%$ of GDP. Fundamental determinants are able to explain only a small part of the deterioration of the current account after 2001, driven by a deteriorating oil balance and the initial net foreign asset position. For 2011, the models predict a current account deficit in the range of 3\% to $4 \%$ of GDP.

Figure 1. Baseline: Actual and fitted current account balance

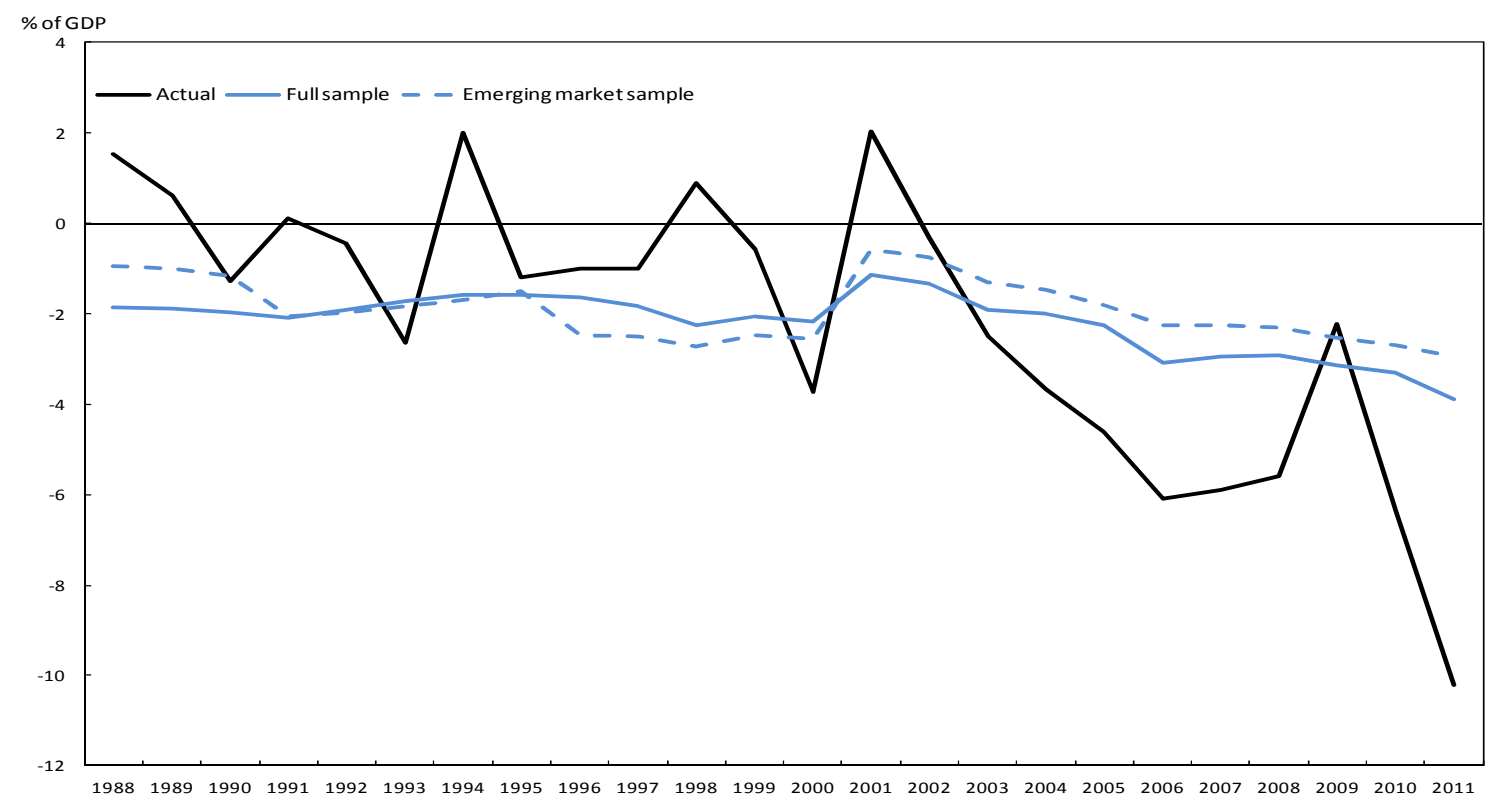

Note: Five-year moving averages of the explanatory variables are used to calculate the fitted current account balances. Estimates are based on Table 1.

Source: OECD estimates.

\section{Structural policies}

22. Table 2 displays the estimation results when structural policy variables related to financial market development and institutional quality are added to the regressions. ${ }^{3}$ The full sample results show a strong negative relationship between growth in private credit and the current account balance. Private credit to GDP growth 10 percentage points above the world average is associated with a decline of the current account balance by about 1 percentage point of GDP. The interpretation of this result is not straightforward and might depend on a country's circumstances. Strong credit growth might be due to the removal of credit constraints and hence be part of a catching-up process in financial development. On the other hand, as the global crisis has shown, strong credit growth might reflect lax credit conditions and excessive household

3. A variable capturing business regulations was not found to be robustly related to the current account. Since this variable is only available for a shorter time period and country sample the results are not shown. 
ECO/WKP(2012)65

Table 2. Structural determinants

\begin{tabular}{|c|c|c|c|c|c|c|c|c|c|c|c|c|}
\hline \multirow[b]{2}{*}{ Variable } & \multicolumn{4}{|c|}{ Full sample } & \multicolumn{4}{|c|}{ Emerging market economies } & \multicolumn{4}{|c|}{ Industrialised countries } \\
\hline & $\begin{array}{l}\text { Posterior } \\
\text { inclusion } \\
\text { probability }\end{array}$ & $\begin{array}{c}\text { Conditional } \\
\text { mean }\end{array}$ & $\begin{array}{l}\text { Conditional } \\
\text { standard } \\
\text { deviation }\end{array}$ & $\begin{array}{c}\text { Conditional } \\
\text { t-statistic }\end{array}$ & $\begin{array}{l}\text { Posterior } \\
\text { inclusion } \\
\text { probability }\end{array}$ & $\begin{array}{c}\text { Conditional } \\
\text { mean }\end{array}$ & $\begin{array}{l}\text { Conditional } \\
\text { standard } \\
\text { deviation }\end{array}$ & $\begin{array}{l}\text { Conditional } \\
\text { t-statistic }\end{array}$ & $\begin{array}{l}\text { Posterior } \\
\text { inclusion } \\
\text { probability }\end{array}$ & $\begin{array}{c}\text { Conditional } \\
\text { mean }\end{array}$ & $\begin{array}{c}\text { Conditional } \\
\text { standard } \\
\text { deviation }\end{array}$ & $\begin{array}{c}\text { Conditional } \\
\text { t-statistic }\end{array}$ \\
\hline Initial net foreign assets & 100 & 0.036 & 0.007 & 4.849 & 100 & 0.027 & 0.007 & 3.721 & 100 & 0.059 & 0.010 & 6.203 \\
\hline Oil trade balance & 100 & 0.379 & 0.054 & 7.008 & 100 & 0.308 & 0.055 & 5.584 & 65 & 0.296 & 0.121 & 2.445 \\
\hline Inflation & 20 & 0.016 & 0.008 & 1.985 & 24 & 0.019 & 0.010 & 1.855 & 8 & 0.027 & 0.014 & 2.010 \\
\hline Trade openness & 0 & -0.004 & 0.006 & -0.622 & 1 & 0.000 & 0.007 & 0.031 & 100 & 0.039 & 0.011 & 3.568 \\
\hline Budget balance & 60 & 0.172 & 0.070 & 2.452 & 19 & -0.193 & 0.117 & -1.643 & 98 & 0.317 & 0.110 & 2.873 \\
\hline Relative income & 3 & -0.027 & 0.030 & -0.915 & 1 & -0.002 & 0.014 & -0.159 & 4 & 0.027 & 0.016 & 1.672 \\
\hline Relative income squared & 1 & 0.000 & 0.000 & 1.625 & 2 & 0.000 & 0.000 & -0.803 & 5 & 0.000 & 0.000 & 1.728 \\
\hline GDP growth & 1 & 0.129 & 0.117 & 1.102 & 5 & 0.170 & 0.146 & 1.164 & 1 & -0.197 & 0.193 & -1.023 \\
\hline Old age & 0 & -0.037 & 0.066 & -0.564 & 6 & -0.084 & 0.073 & -1.147 & 2 & 0.114 & 0.126 & 0.904 \\
\hline Young age & 30 & 0.105 & 0.052 & 2.025 & 1 & 0.007 & 0.027 & 0.252 & 2 & 0.096 & 0.089 & 1.077 \\
\hline Population growth & 22 & -1.255 & 0.542 & -2.315 & 2 & 0.248 & 0.352 & 0.706 & 90 & -2.024 & 0.761 & -2.659 \\
\hline Terms of trade growth & 23 & 0.205 & 0.101 & 2.041 & 83 & 0.280 & 0.112 & 2.504 & 0 & 0.059 & 0.144 & 0.408 \\
\hline Asia dummy & 100 & 4.595 & 0.974 & 4.718 & 100 & 5.557 & 0.889 & 6.248 & & & & \\
\hline Financial centre & 97 & 3.009 & 0.941 & 3.196 & 4 & -2.498 & 2.380 & -1.049 & 0 & 0.729 & 1.068 & 0.683 \\
\hline Euro core dummy & 0 & 0.396 & 1.037 & 0.382 & & & & & 1 & 0.605 & 1.018 & 0.595 \\
\hline Euro periphery dummy & 80 & -3.121 & 1.120 & -2.786 & & & & & 53 & -2.417 & 1.052 & -2.298 \\
\hline EU accession dummy & 99 & -4.780 & 1.377 & -3.471 & 100 & -5.710 & 1.299 & -4.397 & & & & \\
\hline Financial integration & 0 & 0.001 & 0.001 & 0.724 & 2 & -0.002 & 0.002 & -0.833 & 1 & -0.001 & 0.001 & -0.924 \\
\hline Labour force participation & 2 & 0.048 & 0.045 & 1.060 & 1 & 0.015 & 0.060 & 0.256 & 12 & -0.116 & 0.072 & -1.606 \\
\hline Capital account openness I & 0 & 0.137 & 0.227 & 0.605 & 11 & -0.352 & 0.248 & -1.416 & 3 & 0.553 & 0.473 & 1.170 \\
\hline Capital account openness II & 4 & -0.590 & 0.426 & -1.385 & 3 & -0.569 & 0.470 & -1.209 & 2 & -1.309 & 1.092 & -1.199 \\
\hline Private credit to GDP & 2 & -0.864 & 0.738 & -1.171 & 13 & 1.586 & 1.028 & 1.543 & 6 & -1.152 & 0.758 & -1.520 \\
\hline Growth of private credit to GDP & 98 & -0.093 & 0.028 & -3.278 & 94 & -0.093 & 0.032 & -2.871 & 84 & -0.101 & 0.042 & -2.395 \\
\hline Credit controls & 0 & 0.139 & 0.327 & 0.424 & 4 & 0.441 & 0.428 & 1.030 & 7 & 0.753 & 0.506 & 1.489 \\
\hline Credit market regulations & 1 & 0.328 & 0.266 & 1.233 & 4 & -0.293 & 0.276 & -1.061 & 0 & 0.211 & 0.465 & 0.454 \\
\hline Stock market capitalisation & 2 & -0.517 & 0.551 & -0.938 & 1 & -0.144 & 0.601 & -0.240 & 68 & 1.768 & 0.727 & 2.432 \\
\hline Securities market development & 0 & 0.514 & 0.552 & 0.932 & 15 & 0.851 & 0.574 & 1.483 & 1 & -0.979 & 1.012 & -0.968 \\
\hline Bank concentration & 0 & 0.485 & 1.306 & 0.371 & 5 & -2.052 & 1.775 & -1.156 & 0 & 0.360 & 1.915 & 0.188 \\
\hline Bank entry barriers & 75 & -1.300 & 0.486 & -2.674 & 9 & -0.775 & 0.551 & -1.406 & 99 & -1.966 & 0.599 & -3.284 \\
\hline Privatization of banking sector & 0 & 0.163 & 0.255 & 0.640 & 2 & -0.199 & 0.303 & -0.658 & 23 & 0.671 & 0.346 & 1.942 \\
\hline Banking sector supervision & 25 & -0.779 & 0.383 & -2.035 & 1 & 0.253 & 0.624 & 0.405 & 60 & -0.961 & 0.412 & -2.334 \\
\hline Interest rate controls & 8 & 0.750 & 0.489 & 1.533 & 1 & 0.015 & 0.591 & 0.025 & 3 & 1.092 & 0.890 & 1.226 \\
\hline Property rights \& legal system & 100 & 0.708 & 0.237 & 2.995 & 1 & 0.150 & 0.275 & 0.544 & 96 & 1.157 & 0.434 & 2.667 \\
\hline Labour market regulations & 99 & -0.578 & 0.170 & -3.400 & 1 & 0.150 & 0.269 & 0.558 & 69 & -0.642 & 0.255 & -2.521 \\
\hline Trade restrictions & 2 & -0.347 & 0.358 & -0.970 & 1 & -0.159 & 0.329 & -0.482 & 41 & -1.171 & 0.566 & -2.071 \\
\hline Number of countries & & & 45 & & & & 24 & & & & 21 & \\
\hline Number of observations & & & 199 & & & & 96 & & & & 103 & \\
\hline
\end{tabular}

(1961) and refined by Kass and Raftery (1995) is used. According to this rule, the evidence of a regressor having an effect is weak, positive, strong, or decisive if the posterior inclusion probabilities

lie between $50-75 \%, 75 \%-95 \%, 95 \%-99 \%$ or are greater than $99 \%$, respectively.

Source: OECD estimates. 
borrowing. The estimations also suggest that reducing entry barriers into the banking sector leads to a deterioration of the current account balance. This might be due to the presence of foreign banks and hence better access to foreign savings, but might also indicate better quality of banking intermediation driven by competition, which may spur domestic investment. Similarly, a reduction of labour market regulations is found to reduce the current account balance. This might reflect the positive effect of a more flexible labour market on the overall business environment and hence investment. Stronger property rights and a better legal system affect the current account positively. This is not in line with the theoretical prediction that better property rights protection should positively affect expected investment returns and hence investment. This result might be driven by the fact that this variable is strongly positively correlated with per capita income. Generally, higher income in turn is positively associated with the current account balance. Finally, the results with respect to the baseline variables are little changed except that a stronger effect of the budget balance on the current account is found.

23. In the emerging market sample only private credit growth is robustly related to the current account. One reason for the weak correlation between structural policies and the current account might be the limited variation in this sub-sample. Differences are likely to be more pronounced between developing and developed countries and hence explain the stronger results in the full sample. Regarding the baseline variables, terms-of-trade growth is now found to be positively associated with the current account, suggesting that terms-of-trade-induced income shocks are generally perceived as temporary and thus affect saving.

24. The results in the sub-sample of industrialised countries are very similar to those for the full sample with respect to structural policies. In particular credit growth, banking entry barriers, property rights and labour market regulations are robustly related to the current account. However, the evidence is slightly weaker for most of these variables. In addition, there is some evidence that higher stock market capitalisation affects the current account positively, while the impact of stricter banking regulations and supervision is negative. With respect to the baseline variables the results are little changed. In particular, the initial foreign asset position, the oil balance, population growth, the budget balance and trade openness are all found to be robustly related to the current account balance.

25. Figure 2 again plots the fitted values from the full and the emerging market samples together with the actual current account balance for Turkey. The estimates for both samples show a significant deterioration of the estimated current account balance in the beginning of the 1990s. While these dynamics are driven by the reduction of entry barriers in the banking sector in the full sample, this effect is due to a deterioration of the terms of trade in the emerging market sample. This terms-of-trade effect was partly reversed and together with high inflation rates explains the upward trend in the estimated current account for the emerging market sample in the second half of the 1990s. After 2001 the full sample estimates are relatively stable at around $-3 \%$ of GDP, which reflects offsetting effects from strong credit growth and an improvement in the budget balance. The slight downward trend after 2008 is mainly due to a deterioration of the oil balance and the initial net asset position. In the emerging market sample the downward trend after 2001 is more pronounced albeit from a considerably higher level. This downward trend is mainly due to credit growth as well as sharp periodic deteriorations of the terms of trade. For 2011 the models predict a current account deficit of around $4 \%$ of GDP. 
Figure 2. Structural policies: Actual and fitted current account balance

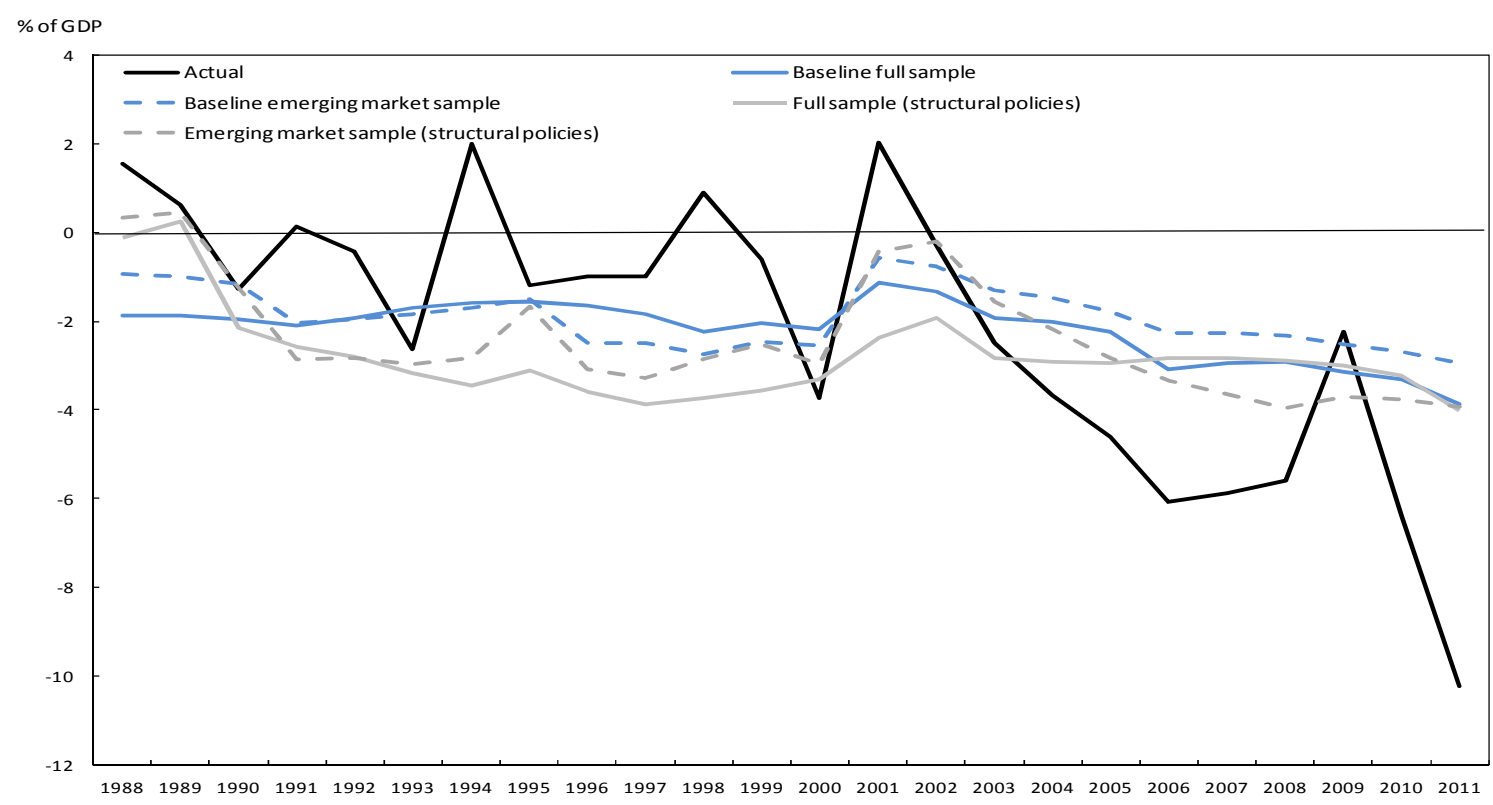

Note: Five-year moving averages of the explanatory variables are used to calculate the fitted current account balances. Estimates are based on Table 2.

Source: OECD estimates.

\section{Current account norms in the medium term}

26. To compute a medium-term current account norm, the estimated relationships have to be combined with predictions for the explanatory variables for Turkey as well as all other countries in the medium term (five years ahead). To this end, projections from the OECD Economic Outlook 91, the new OECD Long-Term Baseline (BLT) for Turkey and the IMF September 2011 World Economic Outlook until 2016 for all other countries have been employed when possible. For other variables values were extrapolated based on past growth rates and structural policy variables were generally held constant (Table 3). Based on these assumptions the estimates suggest a current account norm ranging from $-2.8 \%$ to $-3.8 \%$ of GDP (Figure 3 ). ${ }^{4}$ This is broadly in line with previous findings for Turkey which are in the range of $-2.5 \%$ to $-5 \%$ of GDP (Table 4 ).

4. In additional estimations the dummy for completion of EU accession negotiations was replaced by a dummy capturing the start of negotiation talks, including Turkey. This dummy was only robustly related to the current account in the baseline estimations without financial and institutional variables. Taking this effect into account, the bracket of current account norm estimates would widen to $-4.3 \%$ to $-7.4 \%$ of GDP. However, it is unclear if such an effect is temporary or would persist over the medium-term, and hence if this effect should be captured in the medium-term current account norm. 
Table 3. Medium-term assumptions

\begin{tabular}{|c|c|c|c|}
\hline Variable & $\begin{array}{l}\text { Current value for } \\
\text { Turkey (2011) }\end{array}$ & $\begin{array}{l}\text { Medium-term value } \\
\text { for Turkey (2016) }\end{array}$ & $\begin{array}{l}\text { Medium-term value } \\
\text { for GDP weighted } \\
\text { world (2016) }\end{array}$ \\
\hline Initial net foreign assets & -44 & $-49(2012)$ & n.a. \\
\hline Oil trade balance & -6.4 & -4.8 & n.a. \\
\hline Inflation & 6.5 & 5 & 3 \\
\hline Trade openness & 56 & 50.7 & 65.3 \\
\hline Budget balance & -0.3 & -1.6 & -2.4 \\
\hline $\begin{array}{l}\text { Relative income (relative to GDP weighted } \\
\text { average GDP per capita) }\end{array}$ & 49 & 56.7 & n.a. \\
\hline GDP growth & 8.5 & 5.5 & 4.6 \\
\hline Old age & 8.8 & 9.1 & 18.4 \\
\hline Young age & 38.2 & 34.5 & 28.2 \\
\hline Population growth & 1.3 & 1.1 & 0.7 \\
\hline Terms of trade growth & 2.9 & 0 & n.a. \\
\hline Financial integration & 91.9 & 114.6 & 462.2 \\
\hline Labour force participation & 49.8 & 51.1 & 63 \\
\hline Private credit to GDP & 50 & 81 & 140 \\
\hline Growth of private credit to GDP & 13.3 & 10 & 3 \\
\hline
\end{tabular}

Figure 3. Medium-term current account norms for Turkey

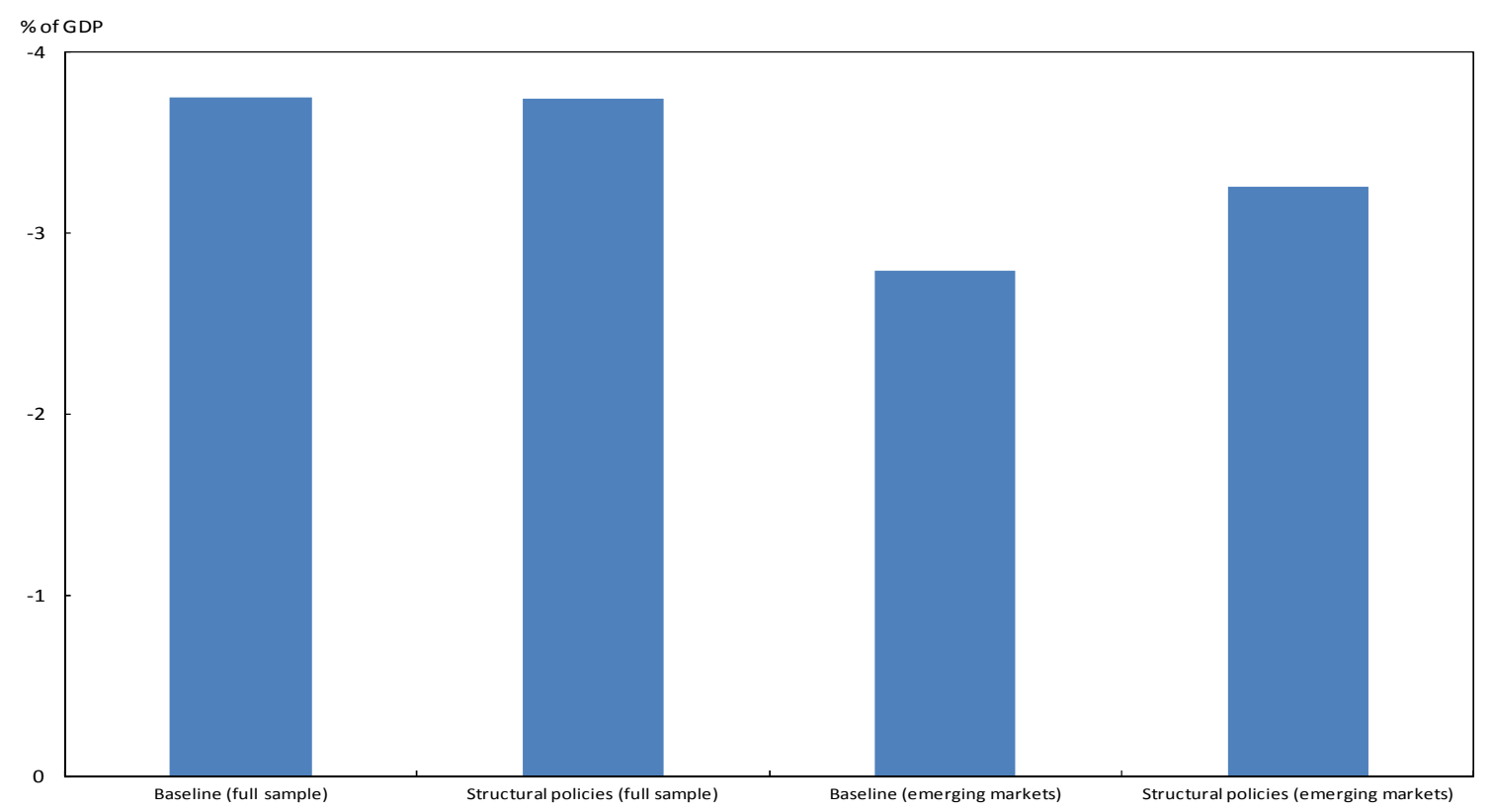

Note: Estimates are based on Table 1 and 2.

Source: OECD estimates. 
ECO/WKP(2012)65

Table 4. Existing current account norm estimates for Turkey

\begin{tabular}{lcc}
\hline Study & $\begin{array}{c}\text { Estimated current account norm in } \\
\text { \% of GDP in the medium term }\end{array}$ & Considered time period \\
\hline Medina et al. (2010) & $-4.9 \%$ & $\begin{array}{c}\text { Estimation: 1970-2008 } \\
\text { Medium-term: } 2014 \\
\text { Estimation: } 1973-2004 \\
\text { Medium-term: } 2011\end{array}$ \\
Lee et al. (2008) 1 & $-3.4 \%$ & $\begin{array}{c}\text { Estimation: } 1980-2005 \\
\text { Medium-term: } 2013\end{array}$ \\
Bussière et al. (2010) & $-2.5 \%$ & Not reported \\
IMF (2010) & $-2.4 \%$ & Not reported \\
\hline Akcay and Ücer (2008) $\quad$ As reported in Medina et al. (2010). & $-3.5 \%$ &
\end{tabular}

\section{Differences between the actual current account and estimated norms}

27. Fundamental saving and investment determinants do not seem able to fully capture the strong downward trend in Turkey's current account deficit since 2001. Differences between the actual current account and estimated norms can reflect cyclical factors but also omitted variables.

28. The real exchange rate, as a proxy for external competitiveness, might be such an omitted factor, which affects the current account mainly through the trade channel. ${ }^{5}$ While variations in the real exchange rate are partly reflected in the norm estimates through the terms-of-trade variable, there, nevertheless, appears to be some correlation between the divergence from the norm and measures of external competitiveness (Figure 4). This correlation is quite strong for a CPI based measure of the real effective exchange rate (Figure 4A) and has the expected negative sign, i.e. exchange rate appreciations are associated with larger negative deviations of the actual from the estimated current account. The correlation is still negative albeit substantially weaker for the ULC based real effective exchange rate (Figure 4B) possibly reflecting the fact that variations in this measure are more closely correlated with terms-of-trade variations.

5. The real exchange rate may affect saving and investment directly. However, the variable was not included in the panel regressions as it is only available for a subset of countries and would have further reduced the already limited sample size. 
Figure 4. Current account norm deviations and external competitiveness
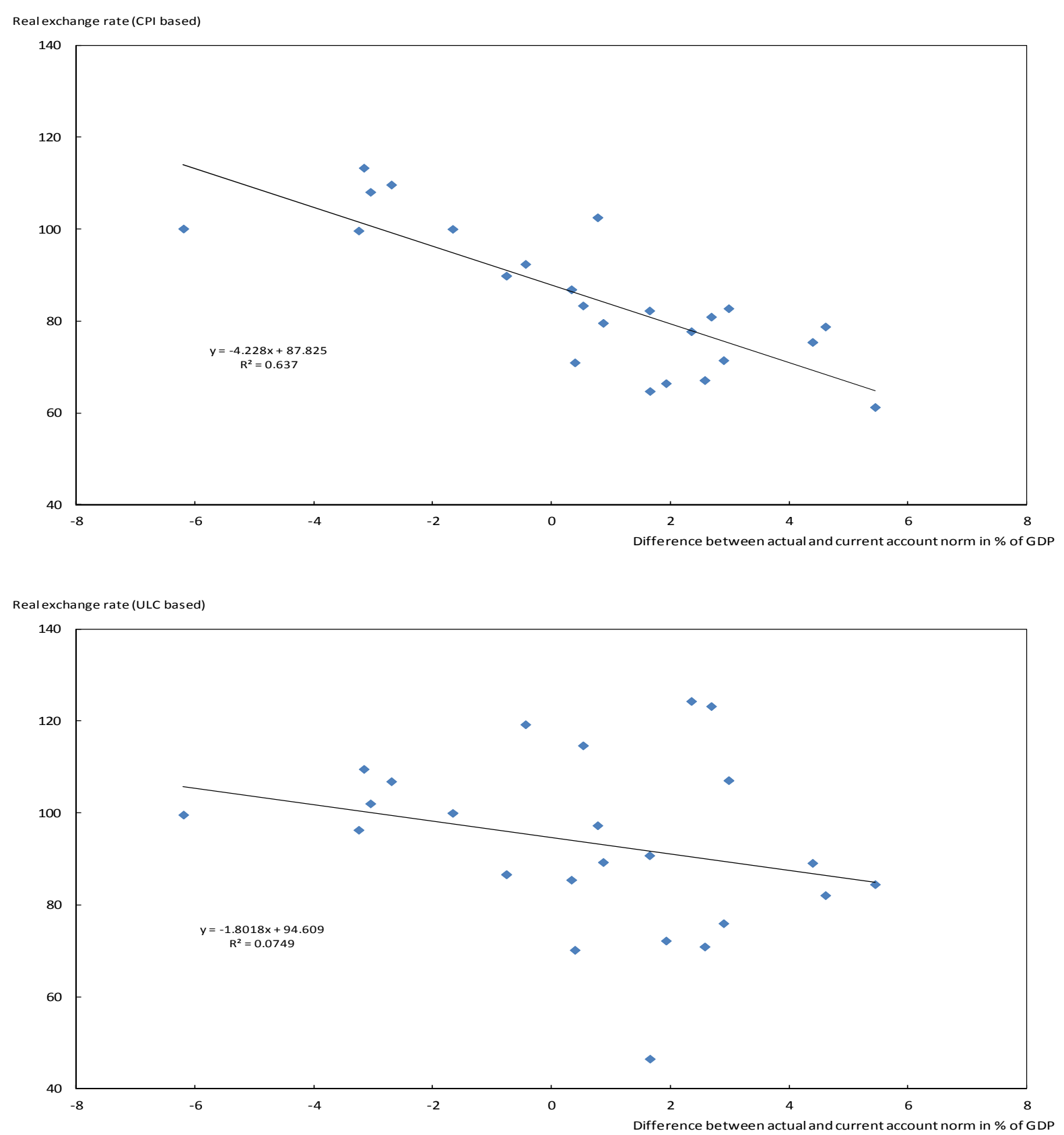

Note: Estimate of the current account norm is based on the results reported in Table 2 for the full sample. Both panels capture the period 1988-2011. External competitiveness is measured by the consumer price index (CPI) or unit labour cost (ULC) based real effective exchange rate. This measure is a weighted average of 48 bilateral exchange rates. The weights are based on a doubleweighting principle, taking into account the structure of competition in both export and import markets of the manufacturing sector of 49 countries (see Brézillon et al., 2010).

Source: OECD calculations.

29. Cyclical factors appear to have played some role in the more recent past (Figure 5). While the correlation between the deviation from the norm and the relative output gap (difference between Turkey's and the OECD output gap) is weak for the entire 1988-2011 sample (Figure 5A), it becomes substantially stronger if only the period since 2000 is considered (Figure 5B). 
ECO/WKP(2012)65

Figure 5. Current account norm deviations and cyclical factors
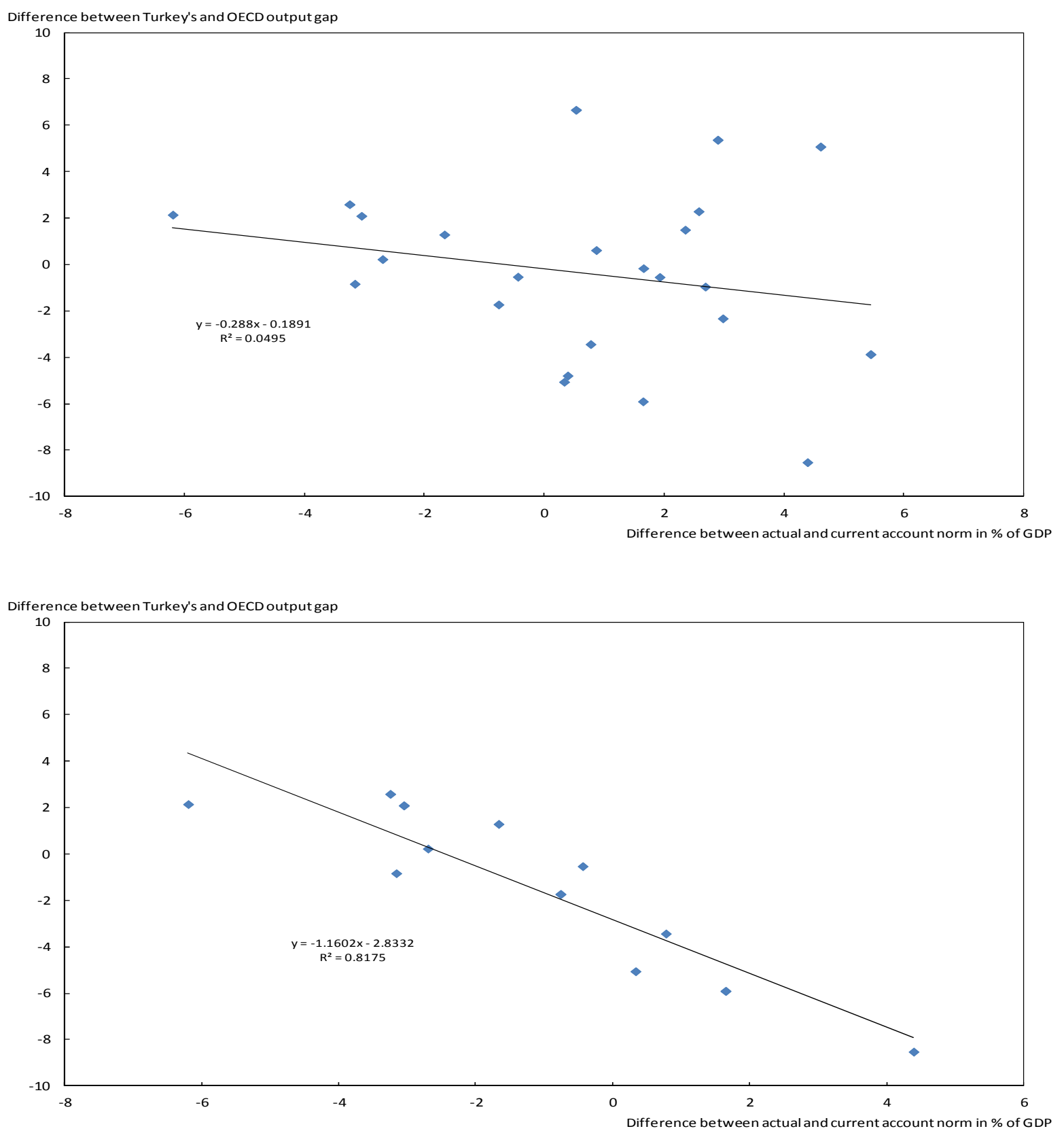

Note: Estimate of the current account norm is based on the results reported in Table 2 for the full sample. The first panel captures the period 1988-2011, while the second captures the period 2000-11.

Source: OECD calculations. 


\section{BIBLIOGRAPHY}

Abiad, A., E. Detragiache and T. Tressel (2008), “A New Database of Financial Reforms”, IMF Working Paper, No. 08/266.

Akcay, C. and M. Ücer (2008), “A Narrative on the Turkish Current Account”, The Journal of International Trade and Diplomacy, Vol. 2, pp. 211-238.

Barnes, S., J. Lawson and A. Radziwill (2010), "Current Account Imbalances in the Euro Area”, OECD Economics Department Working Papers, No. 826.

Baskaya, Y., H. Kara and D. Mutluer (2008), "Expectations, Communication and Monetary Policy in Turkey”, CBRT Working Paper, No. 0801.

Baskaya, Y., E. Gulsen and M. Orak (2010), "2008 Hedef Revizyonu Oncesi ve Sonrasinda Enflasyon Beklentileri”, CBRT Economic Notes, No. 1001.

Beck, T. and A. Demirgüc-Kunt (2009), "Financial Institutions and Markets Across Countries and over Time: Data and Analysis", World Bank Policy Research Working Paper, No. 4943.

Bernanke, B. (2005), "The Worldwide Saving Glut and the U.S. Current Account Deficit", remarks at the Sandridge Lecture, Virginia Association of Economics, Richmond, VA, 10 March.

Bevilaqua, A., M. Mesquita and A. Minella (2007), "Brazil: Taming Inflation Expectations", Central Bank of Brazil Working Papers Series, No. 129.

Brézillon, J., S. Guichard and D. Turner (2010), "Trade Linkages in the OECD Trade System”, OECD Economics Department Working Papers, No. 811.

Bussière, M., M. Ca'Zorzi, A. Chudik and A. Dieppe (2010), "Methodological Advances in the Assessment of Equilibrium Exchange Rates", ECB Working Paper, No 1151.

Ca' Zorzi, M., A. Chudik and A. Dieppe (2009), "Current Account Benchmarks for Central and Eastern Europe: A Desperate Search?”, ECB Working Paper, No. 995.

Ca' Zorzi, M., A. Chudik and A. Dieppe (2012), "Thousands of Models, One Story: Current Account Imbalances in the Global Economy", Journal of International Money and Finance, forthcoming.

Cheung, C., D. Furceri and E. Rusticelli (2010), "Structural and Cyclical Factors behind Current Account Balances”, OECD Economics Department Working Papers, No. 775.

Chinn, M. and H. Ito (2007), "Current Account Balances, Financial Development and Institutions: Assaying the World "Saving Glut"”, Journal of International Money and Finance, Vol. 26, pp. 546569.

Chinn, M. and H. Ito (2008), "A New Measure of Financial Openness", Journal of Comparative Policy Analysis, Vol. 10, pp. 309-322.

Chinn, M. and E. Prasad (2003), "Medium-Term Determinants of Current Accounts in Industrial and Developing Countries: an Empirical Exploration", Journal of International Economics, Vol. 59, pp. 47-76.

Draper, D (1995), “Assessment and Propagation of Model Uncertainty", Journal of the Royal Statistical Society, Vol. 57, pp. 45-97. 
Fernandez, C., E. Ley and M. Steel (2001), "Model Uncertainty in Cross-Country Growth Regressions", Journal of Applied Econometrics, Vol. 16, pp. 563-576.

Gwartney, J., J. Hall and R. Lawson (2011), Economic Freedom of the World: Annual Report 2011, The Fraser Institute, Vancouver, B.C.

Hoeting, J., D. Madigan, A.E. Raftery and C. Volinsky (1999), "Bayesian Model Averaging: A Tutorial”, Statistical Science, Vol. 14, pp. 382-401.

IMF (2010), Turkey: 2010 Article IV Consultation and Post-Program Monitoring, IMF Country Report No. 10/278, IMF, Washington, D.C.

Jeffreys, H. (1961), Theory of Probability, Clarendon Press, Oxford.

Kaas, R. and A. Raftery (1995), "Bayes Factors", Journal of the American Statistical Association, Vol. 90, pp. 773-795.

Kerdrain, C., I. Koske and I. Wanner (2010), “The Impact of Structural Policies on Saving, Investment and Current Accounts", OECD Economics Department Working Papers, No. 815.

Lane, P. and G. M. Milesi-Ferretti (2006), "Capital Flows to Central and Eastern Europe”, IMF Working Paper, No. 188.

Lane, P. and G. M. Milesi-Ferretti (2007), "The External Wealth of Nations Mark II: Revised and Extended Estimates of Foreign Assets and Liabilities, 1970-2004”, Journal of International Economics, Vol. 73, pp. 223-250.

Loayza, N., K. Schmidt-Hebbel and L. Serven (2000), "What Drives Private Saving across the World?", Review of Economics and Statistics, Vol. 82, pp. 165-181.

Lee, J., G. M. Milesi-Ferretti, J. Ostry, A. Prati and L. Ricci (2008), "Exchange Rate Assessment: CGER Methodologies", IMF Occasional Paper, No. 261.

Medina, L., J. Prat and A. Thomas (2010), "Current Account Balance Estimates for Emerging Market Economies", IMF Working Paper, No. 10/43.

Raftery, A. (1995), "Bayesian Model Selection for Social Research”, Sociological Methodology, Vol. 25, pp. 111-163.

Rahman, J. (2008), "Current Account Developments in New Member States of the European Union: Equilibrium, Excess, and EU-Phoria", IMF Working Paper, No. 08/92.

Sala-i-Martin, X., G. Doppelhofer and R. Miller (2004), "Determinants of Economic Growth: A Bayesian Averaging of Classical Estimates (BACE) Approach," American Economic Review, Vol. 94, pp. 813-835.

Weber, A. and C. Yang (2011), "Armenia: An Assessment of the Real Exchange Rate and Competitiveness", IMF Working Paper, No. 11/20.

Wölfl, A., I. Wanner, O. Röhn and G. Nicoletti (2010), "Product Market Regulation: Extending the Analysis Beyond OECD Countries", OECD Economics Department Working Papers, No. 799. 
Annex A: Empirical literature review

Table A1: Empirical studies

\begin{tabular}{|c|c|c|c|c|c|}
\hline Study & Country coverage & $\begin{array}{c}\text { Time } \\
\text { coverage }\end{array}$ & $\begin{array}{c}\text { Estimation } \\
\text { approach }\end{array}$ & Baseline variables & Structural variables \\
\hline $\begin{array}{l}\text { Barnes } \\
\text { et al. (2010) }\end{array}$ & 25 OECD countries & $1969-2008$ & $\begin{array}{l}\text { Static pooled OLS } \\
\text { and fixed effects, 5- } \\
\text { year averages }\end{array}$ & $\begin{array}{ll} & \text { Initial net foreign asset position (NFA) }(++) \\
\text { - } & \text { Budget balance }(++) \\
\text { - } & \text { Old age }(--) \\
\text { - } & \text { Projected old-age }(++) \\
\text { - } & \text { GDP p.c. }(++) \\
\text { - } & \text { GDP growth }(0) \\
\text { - } & \text { Oil price }(--) \\
\text { - } & \text { Trade openness }(++) \\
\text { - } & \text { Euro corm interest rate }(0) \\
& \text { Euro periphery }(-) \\
\end{array}$ & $\begin{array}{ll}- & \text { Credit to private sector }(0) \\
- & \text { Stock market capitalisation (0) } \\
- & \text { Housing investment }(--) \\
- & \text { NAIRU (++) }\end{array}$ \\
\hline $\begin{array}{l}\text { Bussière } \\
\text { et al. (2010) }\end{array}$ & $\begin{array}{l}77 \text { countries ( } 57 \text { emerging } \\
\text { and } 20 \text { industrial) }\end{array}$ & $1980-2005$ & $\begin{array}{l}\text { Bayesian model } \\
\text { averaging (BACE), } \\
\text { 12-year and 4-year } \\
\text { averages }\end{array}$ & $\begin{array}{ll}\text { - } & \text { Initial NFA }(++) \\
\text { - } & \text { Budget balance }(+) \\
\text { - } & \text { Old age }(--) \\
\text { - } & \text { Reung age }(-) \\
\text { - } & \text { GDP growe income }(++) \\
\text { - } & \text { Oil balance }(++) \\
\text { - } & \text { Pode openness }(+) \\
\text { - } & \text { Financion growth }(--) \\
\text { - } & \text { Inian crisis }(++) \\
\end{array}$ & - $\quad$ Civil liberties (reverse order)(+) \\
\hline $\begin{array}{l}\text { Cheung } \\
\text { et al. (2010) }\end{array}$ & $\begin{array}{l}94 \text { countries ( } 30 \text { OECD } \\
\text { and } 64 \text { developing) }\end{array}$ & $\begin{array}{l}\text { 1973-2008 } \\
\text { (baseline), } \\
1994-2008 \\
\text { (with } \\
\text { structural } \\
\text { variables) }\end{array}$ & $\begin{array}{l}\text { Static pooled OLS, } \\
5 \text {-year averages }\end{array}$ & $\begin{array}{ll} & \text { Initial NFA (++) } \\
- & \text { Budget balance }(++) \\
- & \text { Old age }(0) \\
- & \text { Young age }(-) \\
- & \text { Relative income }(+,- \text { emerging } \\
& \text { economies) } \\
- & \text { Relative income squared (- emerging } \\
& \text { economies) } \\
\text { - } & \text { GDP growth }(0) \\
- & \text { Oil consumption per capita (+ emerging } \\
& \text { economies) } \\
- & \text { Oil production }(++) \\
- & \text { Trade openness }(+) \\
\end{array}$ & $\begin{array}{ll}\text { - } & \text { Credit to private sector (-, full } \\
& \text { sample) } \\
\text { - } & \text { Regulatory quality (-, full sample) }\end{array}$ \\
\hline
\end{tabular}


ECO/WKP(2012)65

\begin{tabular}{|c|c|c|c|c|c|}
\hline Study & Country coverage & $\begin{array}{c}\text { Time } \\
\text { coverage }\end{array}$ & $\begin{array}{l}\text { Estimation } \\
\text { approach }\end{array}$ & Baseline variables & Structural variables \\
\hline $\begin{array}{l}\text { Chinn and } \\
\text { Prasad } \\
(2003)\end{array}$ & $\begin{array}{l}89 \text { countries ( } 18 \text { industrial, } \\
71 \text { developing) }\end{array}$ & $1971-95$ & $\begin{array}{l}\text { Static pooled OLS, } \\
\text { dynamic pooled } \\
\text { OLS, 5-year } \\
\text { averages. } \\
\text { Robustness tests: } \\
\text { dynamic fixed } \\
\text { effects }\end{array}$ & 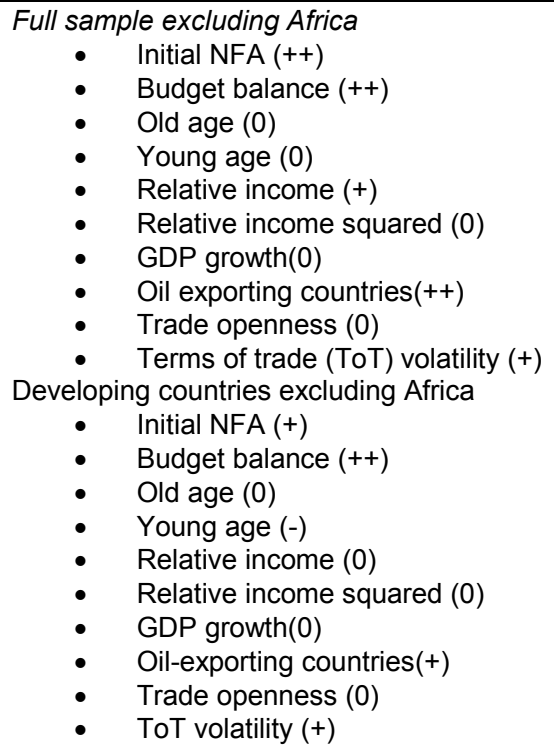 & 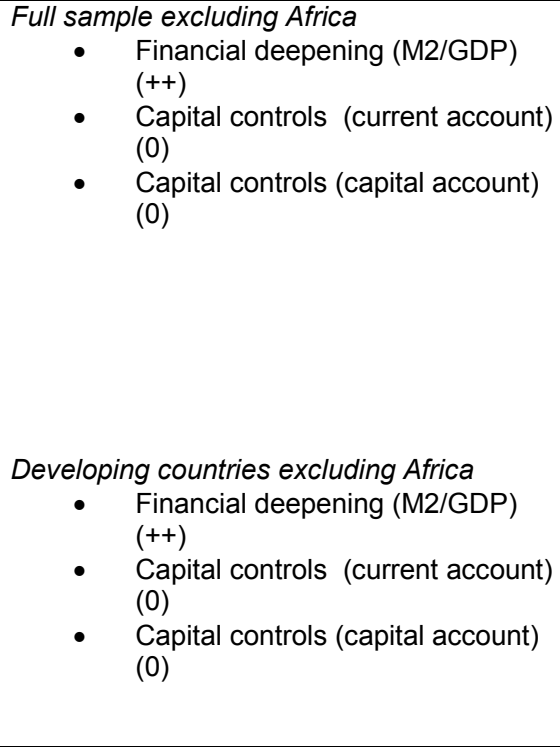 \\
\hline $\begin{array}{l}\text { Chinn and } \\
\text { Ito (2007) }\end{array}$ & $\begin{array}{l}89 \text { countries ( } 19 \text { industrial } \\
\text { and } 70 \text { developing) }\end{array}$ & $\begin{array}{l}\text { 1971-2004 } \\
\text { (baseline), } \\
\text { 1984-2004 } \\
\text { (with } \\
\text { structural } \\
\text { variables) }\end{array}$ & $\begin{array}{l}\text { Static pooled OLS, } 5 \\
\text { years average. } \\
\text { Robustness tests: } \\
\text { fixed effects, } 2 \text { SLS, } \\
\text { GLS }\end{array}$ & 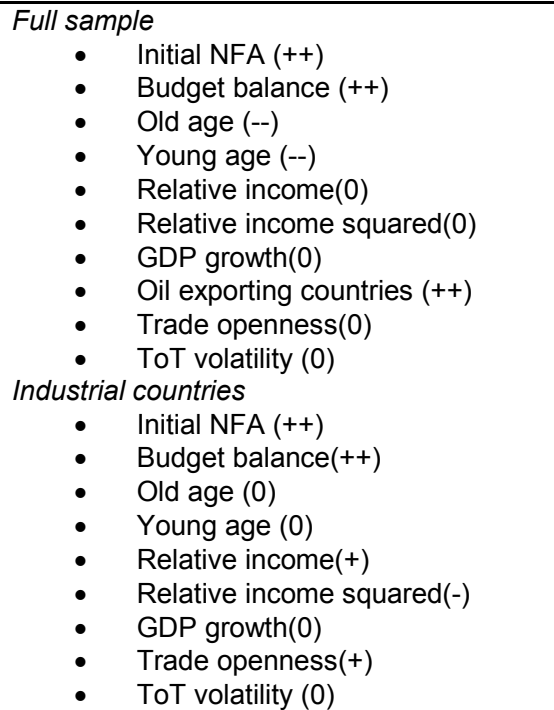 & 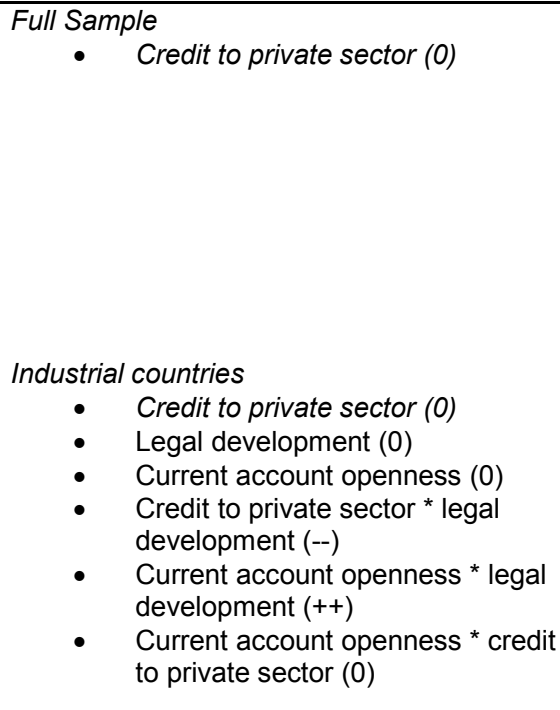 \\
\hline
\end{tabular}




\begin{tabular}{|c|c|c|c|c|c|}
\hline Study & Country coverage & $\begin{array}{c}\text { Time } \\
\text { coverage }\end{array}$ & $\begin{array}{l}\text { Estimation } \\
\text { approach }\end{array}$ & Baseline variables & Structural variables \\
\hline & & & & $\begin{array}{cl}\text { Asian emerging market countries } \\
\text { - } & \text { Initial NFA }(++) \\
\text { - } & \text { Budget balance }(++) \\
\text { - } & \text { Young age }(--) \\
\text { - } & \text { Relative income }(++) \\
\text { - } & \text { Relative income squared }(0) \\
\text { - } & \text { Oil exporting countries }(+) \\
\text { - } & \text { Trade openness }(0) \\
& \text { ToT volatility }(0) \\
\end{array}$ & 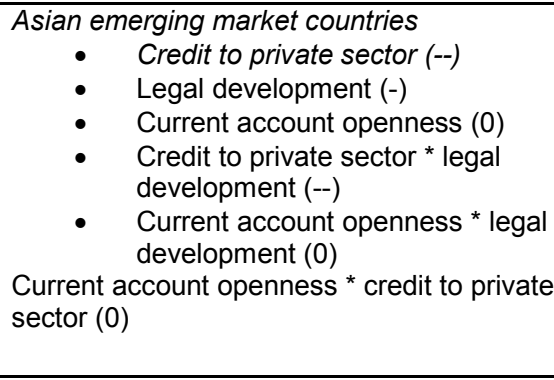 \\
\hline $\begin{array}{l}\text { Kerdrain } \\
\text { et al. }(2010)\end{array}$ & $\begin{array}{l}30 \text { OECD, } 117 \text { OECD and } \\
\text { non-OECD }\end{array}$ & $\begin{array}{l}1965-2008 \\
\text { (OECD } \\
\text { sample), } \\
1993-2008 \\
\text { (full sample) }\end{array}$ & $\begin{array}{l}\text { Error correction } \\
\text { model, annual data } \\
\text { (for OECD sample), } \\
\text { static pooled OLS, } 5 \\
\text { year averages (full } \\
\text { sample) }\end{array}$ & 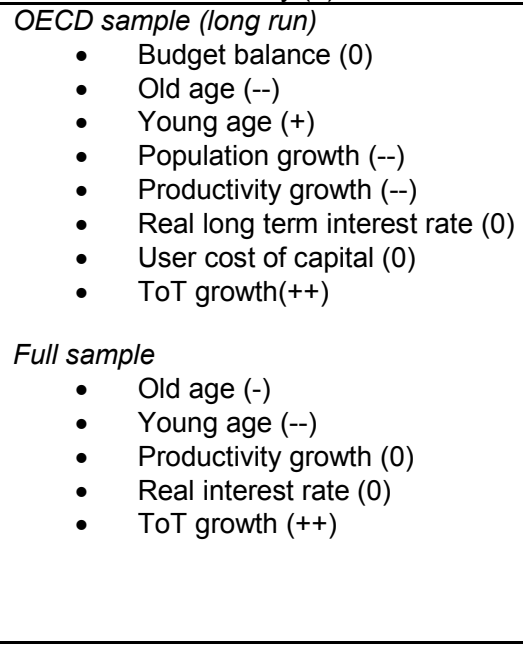 & 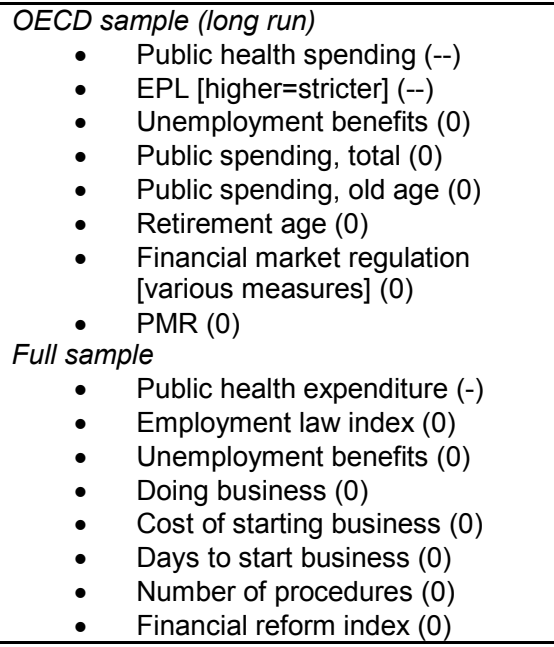 \\
\hline $\begin{array}{l}\text { Lee et al. } \\
(2008)\end{array}$ & $\begin{array}{l}54 \text { advanced and } \\
\text { emerging market } \\
\text { economies }\end{array}$ & $1973-2004$ & $\begin{array}{l}\text { Static pooled OLS } \\
\text { and fixed effects, 4- } \\
\text { year averages }\end{array}$ & $\begin{array}{ll} & \text { Initial NFA }(++) \\
- & \text { Budget balance }(++) \\
- & \text { Old age }(--) \\
\text { - } & \text { Population growth }(-) \\
\text { - } & \text { Relative income }(+) \\
\text { - } & \text { GDP p.c. growth (-) } \\
\text { - } & \text { Bil balance }(++) \\
- & \text { Asian crisis }(++) \\
- & \text { Financial centre }(++)\end{array}$ & \\
\hline
\end{tabular}


ECO/WKP(2012)65

\begin{tabular}{|c|c|c|c|c|c|}
\hline Study & Country coverage & $\begin{array}{c}\text { Time } \\
\text { coverage }\end{array}$ & $\begin{array}{c}\text { Estimation } \\
\text { approach }\end{array}$ & Baseline variables & Structural variables \\
\hline $\begin{array}{l}\text { Medina } \\
\text { et al. }(2010)\end{array}$ & $\begin{array}{l}33 \text { emerging market } \\
\text { economies }\end{array}$ & $1970-2008$ & $\begin{array}{l}\text { Static pooled OLS, } \\
\text { annual data }\end{array}$ & $\begin{array}{ll} & \text { Initial NFA }(++) \\
\text { - } & \text { Budget balance }(++) \\
\text { - } & \text { Old age }(0) \\
\text { - } & \text { Young age }(--) \\
\text { - } & \text { Population growth }(0) \\
\text { - } & \text { GDelative income }(0) \\
\text { - } & \text { Oil balance }(--) \\
\text { - } & \text { Asian crisis }(++) \\
& \text { FDI }(0) \\
\end{array}$ & \\
\hline $\begin{array}{l}\text { Rahman } \\
(2008)\end{array}$ & $\begin{array}{l}59 \text { ( } 21 \text { industrial and } \\
38 \text { developing) }\end{array}$ & $\begin{array}{l}\text { 1971-2006 } \\
\text { (full sample), } \\
1992-2006 \\
\text { (transition } \\
\text { economies) }\end{array}$ & $\begin{array}{l}\text { Static pooled OLS } \\
\text { and fixed effects. } \\
\text { 4-year averages }\end{array}$ & $\begin{array}{ll} & \text { Initial NFA }(++) \\
\text { - } & \text { Budget balance }(++) \\
\text { - } & \text { Old age }(-) \\
\text { - } & \text { Population growth }(--) \\
\text { - } & \text { Relative income }(+) \\
\text { - } & \text { Oil balance }(-) \\
\text { - } & \text { Banking crisis }(++) \\
\text { - } & \text { Asian crisis }(++) \\
\text { - } & \text { Financial Centre }(0) \\
\text { - } & \text { Fem }(-) \\
\end{array}$ & \\
\hline $\begin{array}{l}\text { Weber and } \\
\text { Yang (2011) }\end{array}$ & $\begin{array}{l}54 \text { advanced and } \\
\text { emerging }\end{array}$ & $1969-2008$ & $\begin{array}{l}\text { Dynamic pooled } \\
\text { OLS, 4-year } \\
\text { averages }\end{array}$ & $\begin{array}{ll} & \text { Budget balance (++) } \\
- & \text { Old age (--) } \\
- & \text { Population growth (--) } \\
\text { - } & \text { Rel. income (++) } \\
\text { - } & \text { GDP p.c. growth (--) } \\
\end{array}$ & \\
\hline
\end{tabular}

Notes: ++ positive and highly significant coefficient, + positive and weakly significant or not robust across specifications, 0 insignificant coefficient, -- negative and highly significant coefficient, - negative and weakly significant or not robust across specifications. 
ECO/WKP(2012)65

Annex B: Dataset

Table B1. Data description

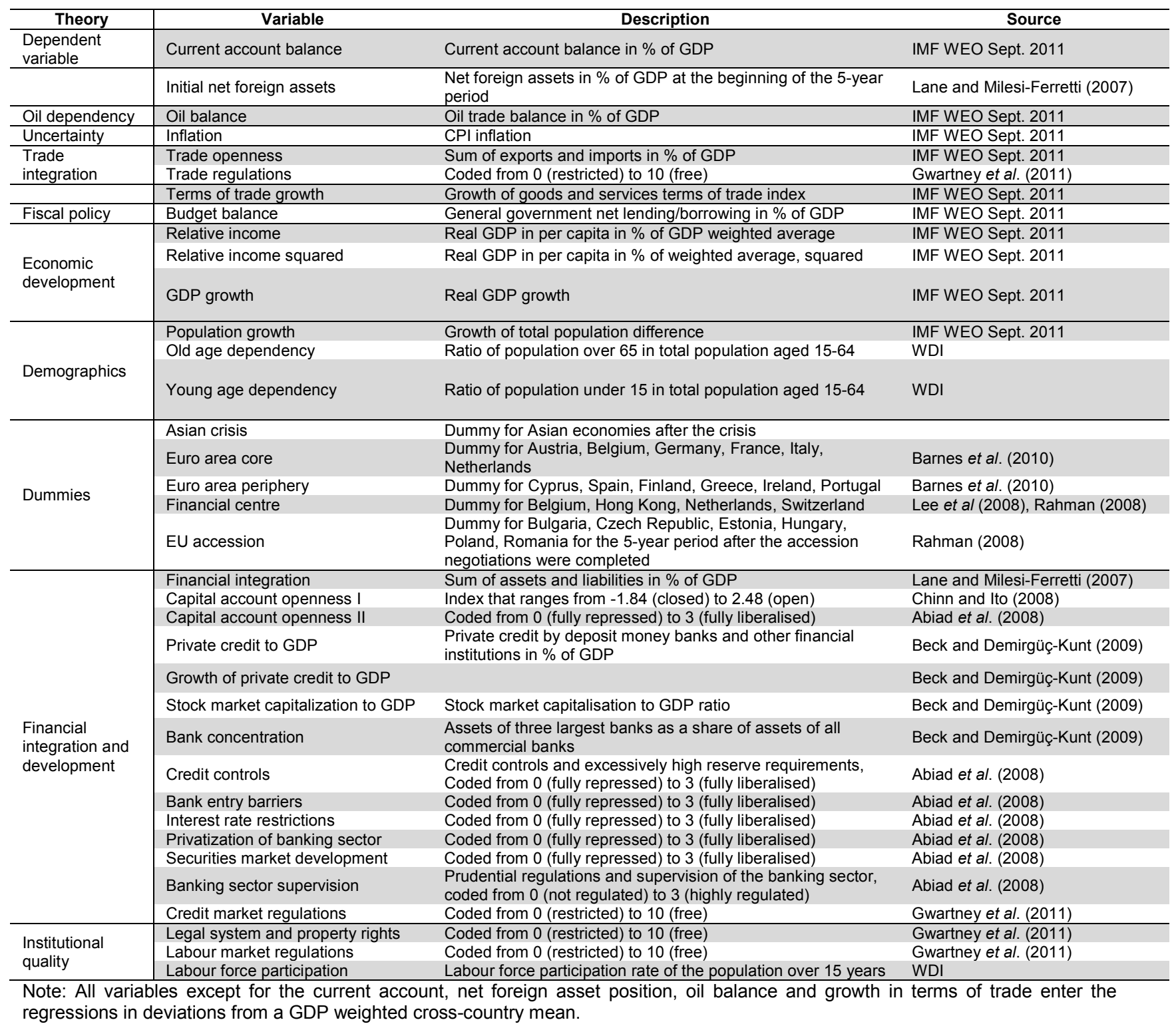


Table B2: Country coverage

\begin{tabular}{|c|c|c|}
\hline Country & Time period in baseline & $\begin{array}{c}\text { Emerging market } \\
\text { sample }\end{array}$ \\
\hline Argentina & 1995-2010 & $x$ \\
\hline Australia & $1985-2010$ & \\
\hline Austria & $1985-2010$ & \\
\hline Belgium & $1985-2010$ & \\
\hline Brazil & $1995-2010$ & $x$ \\
\hline Bulgaria & $1995-2010$ & $x$ \\
\hline Canada & $1985-2010$ & \\
\hline Switzerland & $1985-2010$ & \\
\hline Chile & $1995-2010$ & $x$ \\
\hline China & $1985-2010$ & $x$ \\
\hline Colombia & $1985-2010$ & $x$ \\
\hline Cyprus & $1990-2010$ & \\
\hline Czech Republic & $1990-2010$ & $x$ \\
\hline Germany & $1985-2010$ & \\
\hline Denmark & $1985-2010$ & \\
\hline Spain & $1985-2010$ & \\
\hline Estonia & $1990-2010$ & $x$ \\
\hline Finland & $1985-2010$ & \\
\hline France & $1985-2010$ & \\
\hline United Kingdom & $1985-2010$ & \\
\hline Greece & $1985-2010$ & \\
\hline Hong Kong & $1985-2010$ & $\mathrm{X}$ \\
\hline Hungary & $1990-2010$ & $x$ \\
\hline Indonesia & $1990-2010$ & $x$ \\
\hline India & $1985-2010$ & $x$ \\
\hline Ireland & $1985-2010$ & \\
\hline Iceland & $1985-2010$ & \\
\hline Israel & $1990-2010$ & $x$ \\
\hline Italy & $1985-2010$ & \\
\hline Japan & $1985-2010$ & \\
\hline Korea & $1985-2010$ & $x$ \\
\hline Mexico & $1985-2010$ & $x$ \\
\hline Malaysia & $1985-2010$ & $x$ \\
\hline Netherlands & $1985-2010$ & \\
\hline Norway & $1985-2010$ & \\
\hline New Zealand & $1985-2010$ & \\
\hline Pakistan & $1990-2010$ & $x$ \\
\hline Peru & $1995-2010$ & $x$ \\
\hline Philippines & $1985-2010$ & $x$ \\
\hline Poland & $1990-2010$ & $x$ \\
\hline Portugal & $1985-2010$ & \\
\hline Romania & $1995-2010$ & $x$ \\
\hline Russia & $1995-2010$ & $x$ \\
\hline Slovak Republic & $1990-2010$ & $x$ \\
\hline Slovenia & $1990-2010$ & $x$ \\
\hline Sweden & $1985-2010$ & \\
\hline Thailand & $1990-2010$ & $x$ \\
\hline Turkey & $1985-2010$ & $x$ \\
\hline United States & $1985-2010$ & \\
\hline Venezuela & $1985-2010$ & $x$ \\
\hline Vietnam & $1995-2010$ & $x$ \\
\hline South Africa & $1990-2010$ & $x$ \\
\hline
\end{tabular}




\section{WORKING PAPERS}

The full series of Economics Department Working Papers can be consulted at www.oecd.org/eco/workingpapers/

987. Structural reforms to boost Turkey's long-term growth

(September 2012) by Rauf Gönenç, Oliver Röhn, Vincent Koen and Şeref Saygili

986. Tackling Turkey's external and domestic macroeconomic imbalances

(September 2012) by Oliver Röhn, Rauf Gönenç, Vincent Koen and Ramazan Karaşahin

985. Portugal: Solid foundations for a sustainable fiscal consolidation

(September 2012) by David Haugh and Stéphane Sorbe

984. Portugal: Assessing the risks around the speed of fiscal consolidation in an uncertain environment

(September 2012) by Stéphane Sorbe

983. The German labour market: preparing for the future

(September 2012) by Felix Hüfner and Caroline Klein

982. Climate change policies in Germany: make ambition pay

(September 2012) by Caroline Klein

981. Restarting the growth engine in Finland

(September 2012) by Henrik Braconier

980. Import Competition, Domestic Regulation and Firm-Level Productivity Growth in the OECD (September 2012) by Sarra Ben Yahmed and Sean Dougherty

979. Non-Parametric Stochastic Simulations to Investigate Uncertainty around the OECD Indicator Model Forecasts

(August 2012) by Elena Rusticelli

978. Measuring GDP Forecast Uncertainty using Quantile Regressions

(July 2012) by Thomas Laurent and Tomasz Kozluk

977. Implications of output gap uncertainty in times of crisis

(July 2012) by Romain Bouis, Boris Cournède and Ane Kathrine Christensen

976. Avoiding debt traps: financial backstops and structural reforms

(July 2012) by Pier Carlo Padoan, Urban Sila and Paul van den Noord

975. Sluggish productivity growth in Denmark: the usual suspects?

(July 2012) by Müge Adalet McGowan and Stéphanie Jamet

974. Towards green growth in Denmark: improving energy and climate change policies

(July 2012) by Stéphanie Jamet

973. An Analysis of Productivity Performance in Spain before and during the Crisis: Exploring the Role of Institutions

(June 2012) Juan S. Mora-Sanguinetti and Andrés Fuentes 
972. Europe's new fiscal rules

(June 2012) by Sebastian Barnes, David Davidsson and Łukasz Rawdanowicz

971. Credit Crises and the Shortcomings of Traditional Policy Responses

(June 2012) by William R. White

970. International Capital Mobility and Financial Fragility

Part 7. Enhancing Financial Stability: Country-specific Evidence on Financial Account and

Structural Policy Positions

(June 2012) by Rudiger Ahrend and Carla Valdivia

969. International Capital Mobility and Financial Fragility

Part 6. Are all Forms of Financial Integration Equally Risky in Times of Financial Turmoil? Asset Price Contagion during the Global Financial Crisis

(June 2012) by Rudiger Ahrend and Antoine Goujard

968. International Capital Mobility and Financial Fragility

Part 5. Do Investors Disproportionately Shed Assets of Distant Countries under Increased

Uncertainty? Evidence from the Global Financial Crisis

(June 2012) by Rudiger Ahrend and Cyrille Schwellnus

967. International Capital Mobility and Financial Fragility

Part 4. Which Structural Policies Stabilise Capital Flows when Investors Suddenly Change their

Mind? Evidence from Bilateral Bank Data

(June 2012) by Rudiger Ahrend and Cyrille Schwellnus

966. International Capital Mobility and Financial Fragility

Part 3. How do Structural Policies affect Financial Crisis Risk? Evidence from Past Crises across $O E C D$ and Emerging Economies

(June 2012) by Rudiger Ahrend and Antoine Goujard

965. Sustaining Korea's convergence to the highest-income countries

(June 2012) by Randall S. Jones and Satoshi Urasawa

964. Achieving the "low carbon, green growth" vision in Korea

(June 2012) by Randall S. Jones and Byungseo Yoo

963. Promoting social cohesion in Korea

(June 2012) by Randall S. Jones and Satoshi Urasawa

962. Housing price and investment dynamics in Finland

(May 2012) by Christophe André and Clara Garcia

961. Improving health outcomes and system in Hungary

(May 2012) by Mehmet Eris

960. Towards a more inclusive labour market in Hungary

(May 2012) by Rafał Kierzenkowski 